\title{
Reconstruction and evolution of Archean intracaldera facies: the Rouyn-Pelletier Caldera Complex of the Blake River Group, Abitibi greenstone belt, Canada
}

\begin{tabular}{|r|l|}
\hline Journal: & Canadian Journal of Earth Sciences \\
\hline Manuscript ID & cjes-2015-0029.R2 \\
\hline Manuscript Type: & Article \\
\hline Date Submitted by the Author: & 03-Jan-2016 \\
\hline Complete List of Authors: & $\begin{array}{l}\text { Moore, Lyndsay N.; Université du Québec à Chicoutimi, Dépt. Sciences de } \\
\text { la Terre } \\
\text { Daigneault, Réal; Université du Québec à Chicoutimi, Dépt. Sciences de la } \\
\text { Terre } \\
\text { Aird, Hannah M.; California State University Chico, Geological and } \\
\text { Environmental Sciences Department } \\
\text { Banerjee, Neil R.; Western University, Department of Earth Sciences } \\
\text { Mueller, Wulf U.; Module des Sciences de la Terre }\end{array}$ \\
\hline Keyword: & \begin{tabular}{l} 
Archean, subaqueous, caldera, volcanic architecture, facies \\
\hline
\end{tabular} \\
\hline
\end{tabular}




\title{
Reconstruction and evolution of Archean intracaldera facies: the Rouyn-Pelletier Caldera Complex of the Blake River Group, Abitibi greenstone belt, Canada
}

\author{
Moore, L.N. ${ }^{\mathrm{a}}$, Daigneault, R. ${ }^{\mathrm{a}}$, Aird, H.M. ${ }^{\mathrm{b}}$, Banerjee, N.R. ${ }^{\mathrm{c}}$ and Mueller, W.U. ${ }^{\mathrm{a}, 1}$ \\ ${ }^{a}$ Centre d'études sur les ressources minérales (CERM), Université du Québec à Chicoutimi (UQAC) \\ 555 boul. de l'Université, Chicoutimi, Québec, Canada, G7H 2B1 \\ ${ }^{\mathrm{b}}$ Geological and Environmental Sciences Department (GEOS), California State University - Chico, \\ Chico, California, 95929 \\ ${ }^{c}$ Department of Earth Sciences, Western University, London, Ontario, N6A 5B7 \\ ${ }^{1}$ Deceased on May $16^{\text {th }}, 2010$
}

Corresponding Author: lyndsay.moore@uqac.ca

Telephone: 1-418-545-5011

Fax: 1-418-545-5012

Present Address: Université du Québec à Chicoutimi, 555 boul. de l'Université, Chicoutimi, Québec, Canada, G7H 2B1 
1

2 Sub-vertically- to vertically-dipping Archean strata provide an excellent opportunity to study

3 synvolcanic structures and internal organization of subaqueous volcanic complexes. The Abitibi

4 greenstone belt in Quebec, Canada, hosts a number of these volcanic complexes and specifically

5 the unique Blake River megacaldera complex (BRMCC). The BRMCC is composed of 1) an

6 initial shield phase known as the Misema caldera and 2) two graben-type calderas known as the

7 New Senator and Noranda calderas. The southern portion of the New Senator caldera (SNSC),

8 the focus of this study, is of particular interest as the structure hosts the $54 \mathrm{Mt}$ Horne Au-rich

9 VMS deposit.

Detailed facies mapping, coupled with geochemical and geochronological analysis at multiple outcrop localities throughout the city of Rouyn-Noranda, Quebec, show that the stratigraphy of the SNSC is dominated by subaqueous effusive mafic volcanic facies with local felsic effusive and intrusive deposits. With the incorporation of structural data, we have used synvolcanic faults and dyke complexes to divide these facies into specific blocks within this region, here renamed the Rouyn-Pelletier sector. This study focuses on the facies and characteristics of the Pelletier, Senator and Glenwood blocks and identifies the Évain, Stadacona and Chadbourne blocks.

Geochronological analysis reveals that facies of the Glenwood block are approximately the same age as those of the felsic flows of the previously identified Horne block. Together, all extrusive and intrusive volcanic facies from the Stadacona unit north to the Horne Creek Fault compose a large caldera complex known as the Rouyn-Pelletier caldera complex.

Key words: Archean, subaqueous, caldera, volcanic architecture, facies 


\section{$\underline{1.0 \text { Introduction }}$}

24 The Abitibi greenstone belt is the world's largest greenstone belt and has been explored and

25 studied for over 100 years for orogenic gold and VMS deposits. For the latter, much focus has

26 been placed upon the belt's vast mineral wealth, such as the world class Horne (Dimroth et al.,

27 1982; Gibson and Watkinson, 1990; Kerr and Gibson, 1993), LaRonde-Penna (Mercier-

28 Langevin et al., 2007 a, b) and Kidd Creek (Hannington et al., 1999) deposits. However, sub-

29 vertically- to vertically-dipping strata in a terrain dominated by volcanic units provide a wealth

30 of information regarding the internal architecture of the volcanic edifices hosting these deposits.

31 Pearson and Daigneault (2009) brought renewed interest to the volcanic evolution of the Blake

32 River Group in the Abitibi greenstone belt when they proposed the presence of a large

33 megacaldera complex known as the Blake River Megacaldera Complex (BRMCC) (Fig. 1). The

34 complex consists of the large 40 x $80 \mathrm{~km}$ Misema Caldera with two smaller interior nested

35 caldera structures known as the New Senator Caldera (14 x $35 \mathrm{~km})$ and the Noranda Caldera (15

$36 \times 20 \mathrm{~km})$. These dimensions represent the present dimensions of the complexes and do not take

37 into account the shortening effect associated with the regional deformation. The Noranda

38 Caldera (or Noranda “cauldron") has been recognized for decades (Gibson, 1989; Kerr and

39 Gibson, 1993) but the proposition of an older nested caldera structure (New Senator Caldera) and

40 a host megacaldera (Misema Caldera) have implications for mineralization outside the central

41 camp (Mueller et al., 2008; Pearson and Daigneault, 2009).

42 The volcanic stratigraphy south of the Noranda camp is of particular interest because of the 54

43 Mt gold-rich volcanogenic massive sulfide (VMS) Horne deposit located just south of the Horne

44 Creek Fault. To date, the stratigraphy of the Horne block has not been confidently correlated 
45 across the Horne Creek Fault and into the Noranda camp (Gibson et al., 2000; Monecke et al.,

46 2008); leaving the question of the stratigraphic and structural relationship between the Horne

47 deposit and the central camp. Compilations of previous radiometric dating and new

48 geochronological analysis of the Blake River Group by McNicoll et al. (2014), show that several

49 VMS deposits (e.g. Quemont, Horne, Fabie and Hébécourt) correlate with a cycle of eruptive

50 events at approximately 2702 Ma that pre-date the central Noranda camp by almost four million

51 years. Given the lack of correlation with the stratigraphy of the central camp and an age

52 difference of approximately four million years (even considering age uncertainties), it is

53 plausible that the Horne deposit formed in relation to a different volcanic complex.

54 Detailed mapping conducted by Moore et al. $(2012 ; 2014)$ on successions south of the Horne

55 deposit shows that the stratigraphy of the southern Rouyn-Noranda area is dominated by effusive

56 mafic sequences with ponded lavas (Fig. 2; Moore et al., 2012) interspersed with infrequent

57 felsic volcanic deposits (e.g. the Glenwood Felsic Flow Complex; Moore et al., 2014). These

58 individual events within the southern sector of the New Senator Caldera (NSC) structure as

59 defined by Pearson and Daigneault (2009), suggest the presence of a dominantly effusive

60 subaqueous volcanic complex. The focus of this study is to formulate a complete stratigraphic

61 model of the volcanic and intrusive facies within this sector of the NSC, determine their

62 relationship with the host volcanic environment and determine if facies of the Horne block are

63 associated with these facies directly south of it. Detailed facies analysis, in conjunction with

64 geochemical and geochronological studies, is employed to identify distinct eruptive events.

65 In the first segment of this paper we present detailed facies, petrographic and geochemical

66 analysis of numerous outcrops located across a region from south of the Horne Creek Fault to the

67 northern shore of Lac Pelletier (Fig. 2). These analyses are divided into mafic and felsic 
68 volcanic deposits to emphasize 1) the typical initial mafic basal stratigraphy characteristic of

69 seamounts in arc environments and 2) the evolution to a more bimodal system. Following this, a

70 comprehensive volcanic model integrating all of these eruptive events in the context of a single

71 volcanic complex within the BRMCC will be proposed.

\section{$72 \underline{2.0}$ General Geology}

\section{$73 \quad 2.1$ Abitibi Greenstone Belt}

74 The Abitibi greenstone belt, located in the Superior Province of Canada, is an east-trending

75 volcanic-sedimentary belt intruded by numerous plutonic suites. The $300 \mathrm{x} 700 \mathrm{~km}$ belt

76 straddles the modern day Ontario and Quebec geopolitical boundary and is divided into northern

77 and southern domains (Northern and Southern Volcanic Zones - NVZ and SVZ respectively) by

78 the Destor-Porcupine-Manneville Fault Zone (see inset; Fig. 1) (Dimroth et al., 1982; Ludden et

79 al., 1982; Chown et al., 1992). Thurston et al. (2008) interpret that this subdivision does not

80 exist due to the similar ages of individual lithostratigraphic units in both domains (Thurston et

81 al., 2008).

82 The SVZ is further divided into stratigraphic groups, of which the Blake River Group is a part.

83 The stratigraphy of the BRG was traditionally divided into the Misema and Noranda sub-groups

84 by Goodwin (1977) but was then divided into the Lower and Upper Blake River Groups (Ayer et

85 al., 2002; Goutier et al., 2009). This division remains in Ontario but within Quebec, the BRG is

86 further divided into the Reneault-Dufresnoy, Rouyn-Pelletier, Duprat-Montbray, Hébécourt,

87 Horne, Camac, Dupuis, Bousquet and Noranda Formations by Goutier et al. (2009) and

88 McNicoll et al. (2014). 
89 Subaqueous volcanism formed the BRG over an interval extending from 2704 to $2695 \mathrm{Ma}$

90 (Goutier et al., 2009; McNicoll et al., 2014). The composition of lavas and related volcaniclastic

91 products ranges from basaltic to rhyolitic with affinities ranging from tholeiitic to calc-alkaline

92 (Sterckx et al. 2013; 2014). Early volcanism (Lower Blake River Group) began with the

93 eruption of mostly high Fe to high $\mathrm{Mg}$ tholeiitic basalts interspersed with minor felsic lavas that

94 later transitioned into bimodal volcanism (Peloquin, 2008; Thurston et al., 2008; Goutier et al.,

95 2009). Repeated intrusive activity is represented by numerous plutons and mafic to intermediate

96 dykes and sills.

\subsection{Blake River Megacaldera Complex}

98 The BRMCC has been described in terms of three caldera structures by Pearson and Daigneault 99 (2009): the large, host Misema Megacaldera and two nested and overlapping caldera structures 100 known as the New Senator and Noranda Calderas (Fig. 1; Pearson and Daigneault, 2009, Mueller 101 et al., 2012). The three structures are identified and defined by the distribution and geometry of 102 synvolcanic faults and dyke complexes and the organization of intrusive and volcanic facies.

103 The New Senator caldera is a northwest-trending structure divided into three sectors: the 104 northwest, central and southeast (Mueller et al., 2012; Fig. 1). Tholeiitic to calc-alkaline 105 extrusive and intrusive facies were emplaced between approximately 2702 - $2700 \mathrm{Ma}$ (Mueller 106 et al., 2012; McNicoll et al., 2012).

$107 \quad 2.3$ The Rouyn-Pelletier Sector

108 The study area focuses upon a 4 x $8 \mathrm{~km}$ area of the southeast sector of the New Senator caldera; 109 an area delimited by faults and major dyke complexes and hereby identified as the Rouyn110 Pelletier sector (RPS, Figs. 1, 2). The RPS is bounded to the north by the Horne Creek fault and 
111 to the south by the Stadacona unit (described below). Bounding the western margin of the sector 112 is the NW-trending McPhee dyke complex (also known as the Seguin gabbro); interpreted as a 113 synvolcanic fault by Mueller et al. (2012) and separating the sector from the Évain felsic 114 complex to the west. The eastern limit is less defined due to the effects of deformation and 115 folding but the Gleenwood synvolcanic fault (described below; Mueller et al. 2012) will be 116 considered as an internal limit near a principal one further east that is obscured by deformation.

117 In addition to being fault-bounded, the RPS is also cross-cut by several ENE-trending faults, 118 such as the Andesite Fault, that are interpreted by many authors as synvolcanic in origin (Wilson 119 1941; Gibson and Galley 2007; Moore et al., 2014). The Perreault Fault (informally named) 120 bounding the southern limit of the Glenwood Felsic Flow Complex is one such fault, with 121 associated hydrothermal alteration and hosting a fault-filling mafic dyke. Several NE- and N-S122 trending fault sets are also recognized as synvolcanic. The NE-trending Glenwood Fault is 123 located at the eastern margin of the Glenwood Complex and is defined by hydrothermal 124 alteration, a series of NE-trending gabbroic dykes, and has variable orientation of volcanic facies 125 along its strike; features characteristic of synvolcanic faults (Mueller et al., 2012). Additionally, 126 both the Osisko and Iberville N-trending dyke complexes are also believed to be hosted within 127 primary synvolcanic fractures (Moore et al., 2014). The Osisko dyke complex is N to NE128 trending along its western extent and then extends eastward, forming a T-shaped intrusion and 129 bounding the upper contact of the Glenwood Complex. The N-trending Iberville dyke complex 130 cross-cuts the centre of the Glenwood Complex and is an example of dyke-in-dyke injection with 131 both Archean- and Proterozoic-aged phases (Moore et al., 2014). It is important to note at this 132 time that the amount of displacement and/or subsidence along these faults is often masked by 133 later movement associated with later deformation. 
134 Stratigraphy of the RPS is primarily organized as a north-facing homoclinal sequence with a few 135 rotated or folded panels. In this study, attention will be paid to successions extending from the 136 northern limit of the Stadacona unit (Ross et al., 2008), a 1 x $7 \mathrm{~km}$ east-trending mafic to 137 intermediate volcaniclastic unit (Fig. 2). From this contact to the southern limit of the Horne 138 block (Fig. 2), the stratigraphy of this mostly homoclinal sequence is dominated, in no particular 139 abundance, by basaltic sills and pillowed and massive flows with mainly tholeiitic to transitional 140 magmatic affinities.

141 Volcanic facies north of the Stadacona volcaniclastic unit consist of mafic lavas and intrusions 142 until the Glenwood Felsic Flow Complex (Moore et al., 2014). North, west and east of the 143 Glenwood Complex, volcanic facies are typically mafic to intermediate until just south of the 144 Andesite Fault (Monecke et al., 2008; Moore et al., 2012; Moore et al., 2014). Volcanic facies 145 north of the Andesite Fault are bimodal but dominated by felsic volcanic and volcaniclastic 146 facies of the Horne Block (Fig. 2). Mafic to intermediate intrusions are also a significant facies, 147 with several large intrusions marking major synvolcanic faults such as the McPhee, Osisko and 148 Glenwood dyke complexes (Pearson and Daigneault, 2009; Mueller et al., 2012; Moore et al., 149 2014). All volcanic deposits south of the Horne block have undergone sub-greenschist to 150 greenschist metamorphism (Powell et al., 1995) and weak to moderate alteration such as 151 silicification, carbonatization, chloritization and epidotization (Genna et al., 2011; Moore et al., 152 2012).

\subsection{Deformation of the Rouyn-Pelletier sector}

154 Regional deformation within the Rouyn-Pelletier sector and the Blake River Group in general is 155 largely attributed to a N-S horizontal shortening event (Daigneault et al., 2004; Mueller et al., 
156 2012). The area is characterized by a heterogeneous distribution of ductile deformation. The

157 shortening event primarily manifests as a sub-vertical foliation expressed as a slaty cleavage

158 preferentially developed around synvolcanic faults due to softening facilitated by hydrothermal

159 alteration. This fabric is globally E- to ENE-trending and contains a sub-vertical stretching

160 lineation (Fig. 3a). Overprinting and masking of some primary volcanic textures occurs in

161 relation to this lineation but its sub-vertical attitude allows for the preservation of primary

162 textures and organization in plan view (Y-Z section; Moore et al., 2014).

163 The region between the Perreault Fault and the Stadacona unit (Fig. 2) is considered as a

164 specific structural domain; distinguished from the rest of the north-facing homoclinal sequence.

165 Present within the domain are two distinct, east-trending fold axial traces directly south of the

166 Glenwood Felsic Complex (Fig. 2) (Mueller et al., 2012). These folds are moderately open in

167 their western extent but become more closed further to the east, exhibiting an overall Z

168 asymmetry. This folding is particularly well expressed at Locality A (Fig. 4). Measured values

169 of $\mathrm{S}_{0}$ taken at brecciated flow margins of massive mafic lava flows and plotted on a stereonet.

170 When plotted on a great circle, the poles of these measurements delineate the closing of a

171 syncline, withpoles indicating a fold axis plunging 45 degrees to the east (Figs. $3 \mathrm{~b}, \mathrm{c})$. The

172 observation of molar tooth structures within pillow lavas in this area is compatible with the

173 presence of a hinge zone.

174 The orientation of major faults and dyke patterns within the RPS is a product of from ductile

175 deformation during the regional horizontal shortening. The impact of this deformation is more

176 developed in the eastern part of the study area. The overall Z-shaped fold pattern in the RPS can

177 be attributed to a clockwise rotation of all elements during a dextral shearing event. This dextral

178 component is compatible with offsets observed along marker horizon such as the McPhee dyke 
179 and shear sense indicators observed in the reactivated E-trending synvolcanic faults (Fig. 5a). By

180 removing this ductile deformation, a reconstruction of pre-folded strata at Locality A can be

181 interpreted with as a dominant NW-trending attitude (Fig. 5b). Mueller et al. (2012) interpreted

182 this domain as a tilted and rotated block prior to regional shortening and related to a caldera

183 collapse event.

184

185

186

187

188

189

190

191

192

193

194

195

196

197

198

199

200

\section{$\underline{\text { 3.0 Volcanic Facies and Facies Assemblages }}$}

\subsubsection{Field Methodology}

In this study, a series of key outcrops (Fig. 4) were mapped, sampled for geochemical analysis and/or photographed. Mapping was conducted at scales ranging from 1:100 to 1:400 with five to ten metre grid spacing and the assistance of a sub-metric differential GPS. Samples collected for geochemical analysis are representative of the distribution of volcanic facies and selected from areas that exhibit the least amount of surficial and visible alteration. All GPS co-ordinates given for outcrop and sample localities are in the UTM UPS co-ordinate system with NAD83 grid in zone $17 \mathrm{U}$.

Volcanic and intrusive facies in RPS are identified as facies of the Rouyn-Pelletier Formation (Goutier et al., 2009; McNicoll et al., 2014). Tilting of the strata exposes a vertical cross-section, allowing internal architecture to be viewed. This study divides these facies into geographically referenced blocks with boundaries defined by a) facies distribution and organization and b) by synvolcanic faults, fractures and dyke complexes (Fig. 4). These blocks are divided into external and internal domains based on their location relative to the McPhee and Glenwood dyke complexes (Figs. 2, 4). Those blocks located between the two dyke complexes are defined as “internal”, whereas those located outside of these complexes are defined as "external". General 
201 descriptions will be given for facies in both internal and external blocks, with more detailed 202 descriptions given for the Pelletier, Senator and Glenwood blocks (the focus of this study).

203 Mafic pillowed lavas found within all facies associations indicate all deposits erupted into a 204 subaqueous environment. The facies mapped, sampled and/or photographed within the scope of 205 this study are presented and summarized in Table 1 and schematic stratigraphic sections of each 206 block are provided in figure 6.

\section{$207 \quad 3.1$ External Blocks}

\subsubsection{Stadacona Block}

209 The Stadacona block is bounded to the north by the Stadacona volcaniclastic unit described by

210 Ross et al. (2008) and to the south by the CLLFZ (Figs. 2, 4). Facies of the block are dominated 211 by voluminous mafic to intermediate lavas and their associated volcaniclastic products. Fine to 212 medium grained, mafic to intermediate sills and dykes compose the intrusive facies within this 213 region. The majority of lava flows south of the Stadacona unit have a tholeiitic magmatic 214 affinity, whereas several intrusions have tholeiitic to transitional magmatic affinities (Ross et al., 215 2008).

$216 \quad 3.1 .2$ Evain block facies

217 The Evain block is located west of the McPhee Dyke (Figs. 2, 4). The block consists of felsic 218 lavas and associated volcaniclastic deposits of the Évain felsic volcanic centre (Fig. 2). The 219 Évain centre is a $10 \times 1.6 \mathrm{~km}$ complex composed of E-W-trending massive and brecciated felsic 220 flows. Massive flows are quartz- and feldspar-phyric and exhibit columnar jointing (McNicoll et 221 al., 2014). 


\subsubsection{Pelletier Block}

224 The Pelletier block is bounded to the south by the Stadacona volcaniclastic unit and to the north 225 by the Perreault Fault (Figs. 2, 4). Facies of the assemblage (Table 1) are dominantly mafic in 226 composition and consist of massive and pillowed lava flows, sills and rare dykes and felsic

227 volcaniclastic deposits (Fig. 6). Most facies are east-west to east-southeast-trending (Figs. 2, 4)

228 except where two axial fold traces are present just south of the Perreault Fault (Fig. 2).

229 Pillowed and massive mafic lava flows are the most dominant facies of the assemblage

230 (Localities 1 and 2; Fig. 4). Pillowed lavas are closely packed (Figs. 7, 8, 9a) and morphology

231 shows a consistent younging direction to the north. Grain size in the field ranges from aphanitic 232 to fine grained and pillows are often vesiculated or amygdular. Surficial weathering is common 233 and hyaloclastite-rich rims are weathered orange.

234 Mafic massive flows have a maximum thickness of seven metres and a minimum thickness of $235<10 \mathrm{~cm}$ (Fig. 8). Most flows are entirely massive but thicker ones transition laterally into lobate 236 and pillowed flows (Fig. 8). The flows are commonly internally brecciated with mm-scale 237 fractures filled with sub-mm-scale hyaloclastite fragments (Fig. 9b). Columnar jointing is rare 238 but where present is $\mathrm{cm}$ - to m-scale (Fig. 9c). Lobate and pillowed forms are bordered by mm239 scale hyaloclastite fragments that are weathered orange similarly to those present in the 240 brecciated margin facies.

241 Brecciated facies bound the margins of most massive flows and vary in thickness from $<10 \mathrm{~cm}$ 242 to approximately $5 \mathrm{~m}$. All facies have a hyaloclastite-rich matrix containing $\mathrm{mm}$ - to $\mathrm{cm}$-scale 243 hyaloclastite fragments that are altered by iron-rich fluids and have weathered bright orange in 
244 the field (Fig. 9d). Fragments of fractured pillows and pillow rinds are also present within this

245 facies and have weathered black and white respectively (Fig. 9e).

246 Mafic sills have an apparent thickness ranging from $<5 \mathrm{~m}$ to approximately $35 \mathrm{~m}$. Primary

247 magmatic layering is present in the largest of the sills and consists of $5-10 \mathrm{~cm}$-thick alternating

248 orange and black bands composed of varying percentages of feldspar and amphibole respectively

249 (Fig. 9f). Feldspar-rich bands are typically fine-grained, whereas mafic-rich bands range from

250 fine- to medium-grained. All sills have well developed chilled margins and the central sill has

251 been intruded but another series of mafic dykes characteristic of re-injection. .

252 Felsic volcaniclastic deposits are the least abundant facies $(<1 \%$ overall) within the block and

253 occur in isolated exposures near its southern limit (Fig. 4). These units appear conformably

254 interbedded with pillowed units and consist of normally graded beds with clast sizes ranging

255 from $<0.5 \mathrm{~mm}$ to $8 \mathrm{~cm}$. The fresh surfaces of exposed units are nearly entirely white, making

256 the units easily differentiated from the surrounding mafic units (Fig. 9g).

257 Mafic dykes are both discordant to pillowed and sill facies and intrude mafic sills. Within a large

258 central sill, mafic dykes are centimetre- to metre-scale and taper and anastomose laterally (Fig.

259 9h). Wispy terminations and dismembered morphology are also present in several dykes,

260 consistent with intrusion into a cooling, viscoelastic medium (i.e. Moore et al., 2014). Overall,

261 most dykes are fine-grained with aphanitic chilled margins and are altered (Table 1).

262 3.2.2 Senator Block

263 The Senator block (Table 1) is characterized by ponded mafic lavas, mafic intrusions and minor

264 massive and pillowed lavas. The block is bounded to the west and east by the McPhee and

265 Osisko dyke complexes respectively. The northern limit of the block extends up to the Horne 
266 Creek Fault and southern limit is bounded by the Perreault Fault (Fig. 2). Ponded lavas with

267 minor hyaloclastite horizons and mafic sills and dykes are the dominant extrusive facies (Moore

268 et al., 2012) [Localities 3, 4 and 5; Fig. 4], with massive and pillowed flows found at the extreme 269 eastern margin of the block (Locality 6; Fig. 4).

270 Ponded lava successions are well documented at three localities within the Senator block (Fig. 4)

271 and it is believed that all three localities represent individual ponded lava sequences (Moore et

272 al., 2012). Massive ponded lavas are typically bounded by hyaloclastite horizons and range in

273 thickness from $<2.5-30 \mathrm{~m}$, with most units less than five metres thick. Thinner units are

274 aphanitic, whereas those that are thicker are medium grained (Fig. 10a) and exhibit sub-ophitic to

275 ophitic textures. Massive units, where in contact with hyaloclastite horizons, have a variolitic

276 texture present for several tens of centimetres proximal to the contact (Fig. 10b).

277 Hyaloclastite horizons vary from poorly to well developed both laterally and vertically with well

278 developed hyaloclastite horizons exhibiting several prominent primary volcanic structures: v-

279 shaped structures, cigar structures and pillowed forms (Moore et al., 2012). The v-shaped

280 structures are filled with $\mathrm{mm}$ - to cm-scale hyaloclastite fragments that entrain elongated blebs of

281 lava resembling cigars (cigar structures; Fig. 10c). Pillowed forms can form independently or

282 can grade laterally outward from v-shaped structures. These forms are predominantly ovoid

283 (Fig. 10d) and can be up to several metres in diameter. Hyaloclastite fragments weather orange

284 in the field, have angular and polycuspate forms and $\mathrm{mm}$ - to $\mathrm{cm}$-scale in size.

285 Mafic dykes and sills are the dominant intrusions within the Senator block. Mafic sills are often

286 found concordant to massive ponded lavas and mafic dykes are found at most localities. Most

287 dykes range in thickness from $<20 \mathrm{~cm}$ to approximately 7 metres wide and have an aphanitic to 
288 sub-ophitic texture. Mafic sills are up to 30 metres thick, with these thicker sills having an 289 aphanitic texture at their margins and a sub-ophitic to ophitic texture in their interiors.

290 At the eastern margin of the block, ponded lava facies and well developed hyaloclastite horizons 291 are absent. Exposed facies consist of alternating massive and pillowed flows that show the 292 greatest degree of deformation within mapped facies of the SNSC (Fig. 11). Exposed thickness 293 of massive flows ranges from approximately five metres to $<20$ metres. The contacts between 294 the massive flows and bounding pillowed flows are largely transitional with an absence of 295 developed chilled margins, brecciated fragments or hyaloclastite. Lobate structures are present 296 within the massive flow facies (Fig. 10e). Jointing and fractures within these forms are 297 consistent with flow banding and indicate forms are primary volcanic structures.

298 Pillowed flows are the dominant flow facies at the eastern margin of the block. The gradational 299 nature of the contacts with the massive flows makes it difficult to discern the exact thickness of 300 the pillowed flows but one flow ranges from 10-12 metres thick. Pillow morphology varies 301 from rounded and ovoid to elongated and flattened (Fig. 10f). In the latter, this pillow 302 morphology is interpreted as a modification by late ductile deformation localized near the 303 Perreault Fault. synvolcanic intrusions associated with the Glenwood Felsic Flow Complex and the Osisko dyke complex, respectively (Fig. 2). The assemblage is bounded to the west and north by intrusive facies of the eastern arm of the Osisko dyke complex and to the east and south by the Glenwood and Perreault Faults, respectively. The felsic flow facies of the Glenwood Felsic Flow Complex 
310 (Locality 7; Fig. 4) are the dominant facies and are divided into two types: 1) exogenous facies

311 extruded during the building of the complex and 2) late endogenous facies intruding and inflating

312 the host exogenous deposits. All felsic facies are later cross-cut by several mafic dyke

313 complexes (Moore et al., 2014).

314 Exogenous deposits are characterized by four main facies: massive, in situ brecciated, flow 315 breccia and flow-front breccia. The facies become increasingly brecciated from west to east.

316 The massive facies is located on the far western margin of the complex and is represented by m-

317 scale flows. The overall texture of the facies is aphanitic and several synvolcanic structures and

318 textures are present including lobes, detached lobes, locally developed columnar jointing and

319 well developed flow banding (Fig 12a). Detached lobes are also present within the in situ

320 brecciated facies but only where proximal to the massive flow facies as it became gradually

321 more glass-rich and fragment-rich distally (Fig. 12b).

322 The flow breccia and flow-front breccia facies are the dominant facies of the central and eastern

323 exposures of the assemblage. Both facies are characterized by aphanitic to fine-grained

324 fragments entrained in a formerly glassy matrix (Fig. 12c). Fragments of the flow-front breccia

325 facies are similarly aphanitic to fine-grained but are sub-rounded to rounded due to increased

326 transportation and increased abrasion. The amount of matrix between fragments is greatly

327 reduced in comparison to the flow breccia facies and is evidenced by the near "jigsaw-fit" of

328 fragments (Fig. 12d; Moore et al., 2014).

329 The flow breccia and flow-front breccia facies are intruded by quartz- and feldspar-phyric

330 endogenous lobes at the eastern margin of the block. Margins of the lobes are aphyric and

331 locally brecciated where they intrude into the older and cooler deposits of the flow breccia facies. 
332 Where these lobes breach the surface of the flow complex, they begin to brecciate and flow as 333 lava (Fig. 12e). Two radiometric ages were obtained from this facies using U-Pb 334 geochronological analysis; one from a quartz- and feldspar-phyric area in the central complex 335 and one from the brecciated region in the northern sector of the complex. Both ages are very 336 similar at 2702.9 +/- 1.4 Ma and 2702.2 +/- 3.0 Ma respectively (Mueller et al., 2012).

337 Synvolcanic intrusions compose a significant amount of this block. Three prominent gabbroic 338 dyke complexes are recognized; the Glenwood, the Iberville and the Osisko dyke complexes 339 (Fig. 2). The Lac Noranda intrusion (formerly known as the "Kiwanis pluton"; Mueller et al., 340 2012) is an intermediate to felsic intrusion hosted within the Osisko Dyke Complex (Fig. 2) near 341 the northwest margin of the Glenwood Complex (Locality 8; Fig. 4). The composition of the 342 intrusion is mainly quartz diorite to tonalite and is in turn cross-cut by several (predominantly 343 west-east-trending mafic and felsic dyke systems (Fig. 13). The principal plutonic facies is 344 phaneritic and fine- to medium-grained overall (Fig. 12f). Several m-scale zones of 345 chloritization and epidotization also trend west-east across the outcrop. A sample was selected 346 from the main intrusion for $\mathrm{U}-\mathrm{Pb}$ age determination just to the southwest of the mapped area and 347 has an approximate age of 2702.0 +/- 1.6 Ma (Mueller et al., 2012). This intrusive event is 348 relatively contemporaneous with the emplacement of the Glenwood Felsic Flow Complex 349 stratigraphically below it (Mueller et al., 2012; Moore et al., 2014).

350 Several mafic and felsic dykes cross-cut intrusions associated with the Osisko dyke complex 351 (Fig. 13). All felsic dykes are aphanitic to fine grained and appear silicified in the field. Felsic 352 dykes are difficult to discern from the finer-grained dioritic to tonalitic host and could be 353 mingling with felsic volcanic deposits near the margin of the intrusion. Most mafic dykes cross354 cut the host intrusive rocks in a west-east direction with the exception of a few east-southeast- 
355 trending dykes with pronounced jointing (Fig. 12g). Small, often podiform-like, mafic-rich

356 phases are found within the intrusion. One such pod-like intrusion was sampled for U-Pb age

357 analysis and yielded an age of 2696.6 +/- 0.7 Ma (Mueller et al., 2012).

358 The three large mafic dyke complexes that intrude and border the Glenwood Block delineate

359 large synvolcanic fault and are conduits for the majority of dykes that intrude the assemblage and 360 feed mafic flows to the north of the complex (unpublished data, CONSOREM; Moore et al., 361 2014). The width of mafic dykes cross-cutting the assemblage ranges from $\mathrm{cm}$ - to $\mathrm{m}$-scale, 362 whereas length varies from tens of centimetres to hundreds of metres. Numerous dykes have 363 wispy terminations suggesting intrusion into a cooling and plastic medium (Fig. 12h; Moore et 364 al., 2014). Dykes propagate in two main directions: east-west and north-south. A number of 365 dykes strike northwest-southeast and northeast-southwest but these are usually small branches of 366 larger dykes striking in the two principal directions. Most dykes are aphanitic to fine-grained 367 and vesiculation is visible both in the field and in thin section (Moore et al., 2014).

369 The Chadbourne block was not mapped in detail in this study. This block corresponds to the 370 region located immediately to the north of the Glenwood block. Facies of the Chadbourne block 371 are bounded to the north by the Andesite Fault and to the south by the eastern arm of the Osisko 372 dyke complex (Fig. 4). The assemblage is characterized by voluminous mafic to intermediate

373 flows and gabbroic to dioritic intrusions (Fig. 6; Dimroth et al., 1974).

$374 \quad 3.2 .5$ Horne Block

375 The Horne Block is bounded to the north and west by the Horne Creek Fault and to the south by 376 the Andesite Fault. The eastern limit is cross-cut by a large north-south-trending intrusion but it 
377 is interpreted that the mafic to intermediate flow facies that are to the east of this intrusion are

378 conformable and contemporaneous with facies of the western Horne block (i.e. Monecke et al., 379 2008). The two dominant facies of the assemblage are aphyric to quartz-phyric rhyolite flows 380 and associated felsic volcaniclastic deposits that are interpreted to be products of small-volume 381 effusive and explosive eruptive processes (Fig. 6; Monecke et al., 2008; Laurin, 2009).

\section{$382 \quad$ 4.0 Geochemical Analysis}

383 All volcanic and intrusive facies were sampled for geochemical analysis according to lateral 384 and vertical facies transitions. Samples are considered "least altered" based on relatively fresh 385 appearance in the field with minimal surface and hydrothermal alteration such as sericitization, 386 chloritization and carbonatization. Preparation of samples for analysis was conducted at the 387 Université du Québec à Chicoutimi where alteration rinds were removed and samples were 388 crushed and then pulverized in an aluminum ring mill.

Analysis of elemental concentrations in samples was completed at the Geoscience Laboratories

390 (GEOLABS) facility at the Ontario Geological Survey in Sudbury, Ontario, Canada. Fused disk 391 X-ray fluorescence (XRF) was employed for determining concentrations of major oxides $(0.01 \%$ 392 detection limit), whereas trace and rare earth element (REE) concentrations were analyzed using 393 Inductively Coupled Plasma-Mass Spectrometry (ICP-MS). A closed vessel multi-acid digestion 394 was used for ICP-MS analysis and detection limits for element concentrations range from 0.002 395 to $26 \mathrm{ppm}$. To verify precision in the laboratory, duplicate analysis was conducted every tenth 396 sample for both XRF and ICP-MS techniques. For accuracy, GEOLABS' internal certified 397 reference materials were used for one blank and one standard every ten samples. Values for 398 geochemical analysis of collected samples from the Pelletier and Senator blocks are presented in 
399 Appendix A. Values from samples collected from the facies of the Glenwood block are

400 presented in Moore et al., 2014 and values for the ponded lava facies of the Senator block are

401 reported in Moore et al., 2012.

402 To better present analyses and illustrate the evolution of the edifice, analyses will be grouped and

403 presented according to composition: mafic extrusive facies, mafic intrusive facies and felsic

404 extrusive and intrusive facies.

405 4.1 Mafic Extrusive Volcanic Facies

406 Pillowed and massive flows of the RPS plot predominantly within the subalkaline basalt field on

407 the trace element classification diagram but range up to andesitic basalt. Samples plot within

408 two distinct groups: tightly clustered within the centre of the field and in a second cluster

409 extending into the andesitic basalt field (Fig. 14a). All lavas either plot near the base of the

410 tholeiitic field or along the boundary between the tholeiitic and transitional fields of the binary $\mathrm{Y}$

411 vs. Zr magmatic affinity diagram (Fig. 14b).

412 Several distinct REE profiles are present when data is plotted normalized to primitive mantle

413 values on REE diagrams: 1) a tholeiitic profile with slight LREE enrichment; 2) a primitive and

414 relatively flat signature with a slight positive Eu anomaly and 3) a more transitional profile with

415 a moderate LREE concentration (Fig. 15a) (Sun and McDonough, 1989). The transitional

416 affinity and elevated LREE concentrations are potentially an expression of hydrothermal

417 alteration as these samples were notably altered in the field.

$418 \quad 4.2$ Mafic Intrusive Facies 
419 Mafic intrusions of the RPS are typically fine- to medium-grained mafic dykes and sills and 420 show a wider range in composition than mafic extrusive facies. On the trace element

421 compositional diagram, samples from the Pelletier block are typically plot within the subalkaline

422 basalt field, whereas those from the Senator block range from subalkaline basalt to andesite in 423 composition (Fig. 14c). Mafic sills and dykes of the BIFA plot within the tholeiitic field of the 424 binary magmatic affinity diagram of Barrett and MacLean (1999), with the exception of one 425 sample that plots within the transitional field. Samples from mafic intrusive facies of the 426 Glenwood block plot in all three fields; with the majority of samples plotting within the calc427 alkaline field (Fig. 14d).

428 Many of the intrusive facies of the Pelletier and Senator blocks exhibit REE profiles similar to 429 those of mafic extrusive facies with an elevated LREE profile, slight positive Eu anomaly and 430 overall negative slope (Fig. 15b). Mafic intrusive facies of the Glenwood block have more 431 variable REE profiles reflecting their calc-alkaline, transitional and tholeiitic magmatic affinities 432 with LREE profiles with significant negative slopes, marginally negative slopes and relatively 433 flat HREE profiles respectively (Fig. 15b) (Moore et al., 2014).

435 Felsic extrusive and intrusive facies are dominated by the felsic flows of the Glenwood Felsic 436 Volcanic Complex (Locality 7; Fig. 4) within the Glenwood block. These flows have a 437 dacitic/rhyodacitic composition when plotted on the trace element diagram of Winchester and 438 Floyd (1977) (Fig. 14e). All samples have a transitional magmatic affinity (Fig. 14f), further 439 supported by primitive mantle-normalized REE profiles that have elevated LREE concentrations 440 (Fig. 15c) (Sun and McDonough, 1989). All profiles exhibit a variable negative Eu anomaly and 
441 flat HREE trends relative to primitive mantle (Fig. 15c) (Sun and McDonough, 1989; Moore et

442 al., 2014). Elemental concentrations reported by Laurin (2009) for massive rhyolite flows of the

443 Horne block are plotted along with those from the Glenwood block and have a similar

444 rhyodacitic composition (Fig. 14e) but a more calc-alkaline magmatic affinity (14f). Rare earth

445 element profiles for the Horne block felsic flows are similar to felsic flows from the Glenwood

446 block (Fig. 15c). However, this appearance could also be caused by significant hydrothermal

447 alteration. Samples of quartz diorite and tonalite collected from intrusive facies of the Osisko

448 dyke complex (Figs. 2, 4) have similar REE profiles to those of the Horne Mine sequence and

449 the Glenwood block and are characteristic of felsic facies with a transitional magmatic affinity

450 using the criteria of Sun and McDonough) (1989).

451

$452 \quad \underline{5.0}$ Interpretation and Discussion

453 Through the use of detailed facies, geochemical and geochronological analysis, the volcanic

454 evolution of the Rouyn-Pelletier sector can be reconstructed. With the aid of previous studies

455 conducted within the immediate area (i.e. Kerr and Gibson, 1993; Gibson and Galley, 2007; Ross

456 et al., 2008; Monecke et al., 2008 and Ross et al., 2011 a, b) and comparisons to modern

457 subaqueous to emergent volcanic complexes such as those present in the Kermadec (Wright and

458 Gamble, 1999; Wright et al., 2002; Wright et al., 2006), Izu Bonin (Fiske et al., 2001; Tani et al.,

459 2008; Allen et al., 2010) and South Sandwich (Lachlan-Cope et al., 2001; Leat et al., 2010; Leat

460 et al., 2013) arcs, we can reconstruct the complete evolution of the RPS and hypothesize a

461 possible relationship with facies of the Horne block. . 
462 The above described blocks of the RPS are composed of subaqueous volcanic and intrusivefacies

463 emplacedduring the development of a bimodal subaqueous volcanic complex. following

464 development within a bimodal subaqueous complex. This complex is hereby identified as the

465 Rouyn-Pelletier caldera complex (RPCC). The Glenwood and McPhee dyke complexes are

466 hosted within the bounding faults of the complex's subsidence structure and the distance

467 between these faults (caldera diameter) is what necessitates the classification of the complex as a

468 caldera. As described by Lipman (2000), calderas are volcanic-tectonic depressions, ranging in

469 diameter from 2 to $100 \mathrm{~km}$, resulting from the subsidence and collapse of volcanic complexes in

470 relation to the draining of high-level magma chambers.

471 Evidence of subsidence is present within the Pelletier, Senator and Glenwood blocks. As

472 previously described, rotated and folded basaltic flows of the Pelletier block are believed to have

473 been displaced during an initial collapse event. Within the Senator block, massive ponded lavas

474 at Locality 4 have a north-westerly-south-easterly orientation consistent with subsidence along

475 the McPhee complex (Moore et al., 2014). The Glenwood block is hosted within a graben-type

476 structure and is fault-bounded to the north, east, south and west. Subsidence of the Senator block

477 was necessary to allow for the extrusion of felsic facies within the Glenwood block and

478 continued subsidence is indicated by the offset of several mafic dykes cross-cutting felsic facies

479 (Moore et al., 2014). These collapse and subsidence events are discussed in the following

480 paragraphs in the context of the evolution of the RPCC.

481 Initial mafic to intermediate eruptive phases have a predominantly tholeiitic magmatic affinity

482 that evolve to a more transitional bimodal edifice with the emplacement of the Glenwood Felsic

483 Complex. Mafic tholeiitic volcanism continues throughout the development of the caldera with

484 prolonged extrusion of ponded mafic lavas and mafic intrusions along the western margin of the 
485 complex. Several intermediate to felsic facies selected for U-Pb geochronological analysis

486 reveal the approximate age of the edifice to be $2702 \mathrm{Ma}$.

$487 \quad 5.1$ Facies and Geochemical Analysis

$488 \quad 5.1 .1$ Pre-caldera Stage

489 Facies of the pre-caldera stage are found within the Stadacona block (Fig. 4) and represent the

490 extrusive and intrusive facies characteristic of the initial constructional stages of mafic

491 subaqueous seamounts (Cas, 1992; Corcoran, 2000). There is insufficient mapping in the area to

492 determine whether the base of the RPCC is fed by one point source or a series of vents.

493 Constructional activity typically begins as a series of mounds of pillowed lavas and massive

494 flows, which coalesce and build upon the plateau of the edifice (Corcoran, 2000) (Fig. 16a).

495 Mafic to intermediate dykes and sills feed upper level flows and endogenously inflate the

496 complex. Lavas can originate from a single point of origin or they can feed from a series of

497 vents along a fissure or fracture (Cas, 1992). In the instance of multiple feeder systems, the base

498 of the complex builds as a series of amalgamated mounds as opposed to one increasingly larger

499 complex (Cas, 1992). The dimensions and geometry of the underlying chamber is unknown as

500 it is not exposed. There is evidence that caldera magma chambers can have simple single

501 chamber geometries or can be a series of interconnected and/or stacked melt lenses (Cashman

502 and Giordano, 2014). For the purpose of this study, we model the chamber as a simple single

503 chamber.

504 5.1.2 Stage One: Basal Caldera Construction

505 During initial caldera development, inflation of the magma chamber structure leads to the

506 development of a localized extensional regime and initial ring faulting (Lipman, 1997). As 
507 magma is evacuated from the underlying chambers or melt lenses, a void is created beneath the 508 complex (i.e. Lipman, 1997; Geist et al., 2005; Cashman and Giordano, 2014). The weight of 509 the overlying roof structure and lavas begins to depress the upper stratigraphy of the initial 510 seamount and subsidence commences, forming the bounding caldera faults (Fig. 16b) (Walker, 511 1988). Within the study area, these large bounding synvolcanic faults are represented by the 512 McPhee and Glenwood dyke complexes (Fig. 2). The lava flows constructing the upper 513 stratigraphy of this initial mafic edifice subside and then become the first caldera floor. These 514 initial seamount facies and deposits erupted on the first caldera floor are represented in the study 515 area by the mafic flows and sills of the Pelletier block found between the Stadacona 516 volcaniclastic unit and the Perreault Fault (Figs. 2, 4). This large scale collapse and subsidence 517 is evidenced by the rotated and folded structures in mafic lava flows observed at Locality A 518 (Figs. 2, 3b, c) and by the orientation of volcanic units bordering the McPhee dyke complex.

519 The pre-folding north-south orientation of lavas (Fig. 5) suggests that faulting of the caldera 520 floor was significant and several blocks rotated during collapse. This faulting would have 521 subsequently enabled extrusion of lava, feeding small volume eruptions stratigraphically above 522 these structures.

523 Geochemical analysis of intrusive and extrusive facies of pre-caldera facies and the Pelletier 524 block supports the interpretation of an initial mafic volcanism (Moore et al., 2012). Mafic 525 flows, sills and dykes of the pre-caldera facies south of the Stadacona volcaniclastic unit are 526 predominantly basaltic with minor basaltic andesitic and andesitic compositions (Ross et al., 527 2008). These volcanic facies, along with the basaltic to basaltic andesitic flows and intrusions of 528 the Pelletier block, are present in early constructional phases such as those exposed at the 529 Sturgeon Lake caldera (Morton et al., 1991), those found in the Point Lake and Beaulieu River 
530 belts of the Slave province (Corcoran, 2000), the Bay Volacnic Group in Fiji (McPhie, 1995) and

531 the Waiatarua Formation at Maori Bay, New Zealand (Bear and Cas, 2007).

532 5.1.3 Stage Two: Trap-door Collapse

533 Asymmetrical emplacement of small volume eruptions in the western sector of the Senator

534 block, coupled with the lateral extrusion of magma along dykes and sills and differential

535 evacuation from the underlying magma chamber or lenses culminates in incremental collapse

536 and faulting of the caldera floor. For the RPCC, differential evacuation of the magma chamber

537 resulted in a trapdoor collapse on the western margin of the caldera structure (Fig. 16c) (Lipman,

538 1997). In trapdoor geometries, one side of the caldera floor subsides significantly in comparison

539 to the other. The bounding fault of the significantly subsided floor is preferentially more

540 prominent than the opposite bounding fault. A significant collapse is demonstrated by the NW-

541 NNW orientation of volcanic deposits bordering the eastern limit of the McPhee dyke (Fig. 4;

542 Pearson and Daigneault, 2009). This characteristic is observed when comparing the geometries

543 of the intrusive facies of the McPhee dyke and the Glenwood Fault/dyke complex (Fig. 2) in that

544 the intrusion hosted within the McPhee complex is more coherent than the dismembered dykes

545 of the Glenwood complex. This trapdoor geometry facilitated the extrusion of magma allowing

546 the extrusion and accumulation of massive ponded lavas and forming some of the initial deposits

547 of the Senator block (Fig. 16d).

548 Ponded lavas accumulate in synvolcanic depressions such as large collapse structures or in 549 smaller craters and pit craters (Cas, 1992; Gregg et al., 2000; Geist et al., 2005). Multiple

550 localities host ponded lavas on the western margin of the study area between the McPhee and 551 Osisko dykes (Figs. 2, 4), implying there was a significant depression hosting prolonged lava 
552 accumulation (Moore et al., 2012). Pillowed and massive flow facies at the eastern margin of the

553 Senator block (Locality 6, Fig. 4) represent the edge of ponded lava sequences where lavas break

554 and flow along the caldera floor.

555 The orientation of ponded lavas of the Senator block is consistent with continued subsidence

556 along the western margin of the caldera complex (Fig. 4). The overlying weight of ponded lavas,

557 along with continued faulting and seismic activity, caused fracturing of the downward-sloping

558 caldera floor and a more piecemeal-type fault system developed and facilitated the emplacement

559 of the Osisko and Iberville dyke complexes.

560 Massive ponded lavas and intrusions of the Senator block emplaced after faulting and collapse of

561 the first caldera floor range in composition from basaltic to andesitic with tholeiitic to

562 transitional magmatic affinity and represent continuing discharge and emplacement of mafic to

563 intermediate lavas along the McPhee dyke complex. The presence of extrusive and intrusive

564 facies with basaltic to andesitic composition and a more transitional magmatic affinity suggests a 565 more evolved magmatic phase than those of the predominantly tholeiitic Pelletier and pre-caldera 566 Stadacona blocks.

567 5.1.4 Stage Three: Piecemeal Faulting and Bimodal Volcanism

568 Extrusive and intrusive facies of the Glenwood block are consistent with the transition to 569 bimodal activity and development of a second and third caldera floor. The establishment of the 570 fault hosting the Osisko dyke (Fig. 1) provided a significant conduit for the extrusion of magma.

571 This conduit allowed the extrusion of the Glenwood Felsic Flow Complex (Locality 7, Fig. 4) as

572 the first significant phase of felsic extrusive volcanism. The felsic flows of the Glenwood

573 Complex were emplaced as a series of easterly-flowing stacked lobes extruded from an eruptive 
574 centre at or very proximal to the Osisko dyke (Moore et al., 2014) (Fig. 16e). Due to the absence

575 of Glenwood deposits to the west of the Osisko dyke, it is evident that the block of caldera floor

576 immediately to the east of the dyke was tilted and subsided enough to limit the emplacement of

577 flows to the east of the dyke. The complex flowed eastward until it abutted against the uplifted

578 eastern margin of the caldera wall (marked by the Glenwood Fault). As a result, the waning

579 stages of felsic volcanism were then confined endogenously to the eastern margin of the flow

580 complex (Moore et al., 2014).

581 Dacitic to rhyodacitic lavas of the Glenwood Felsic Flow Complex compose the bulk of the

582 Glenwood block and are the first deposits in the RPCC with a) a felsic composition and b) a

583 significantly transitional magmatic affinity (Moore et al., 2014). The appearance of felsic lavas

584 represents the shift to bimodal activity similar to other oceanic arc volcanoes and calderas such

585 as those found in the Kermadec (Wright and Gamble, 1999; Wright et al., 2006), Izu Bonin

586 (Fiske et al., 2001; Allen et al., 2010) and South Sandwich (Leat et al., 2010; Leat et al., 2013)

587 arcs. Intrusions associated with the Osisko dyke complex, such as certain phases of the Lac

588 Noranda pluton, similarly have a more felsic composition and transitional affinity indicating the

589 presence of more evolved lavas and intrusions higher in the volcanic stratigraphy of the RPCC.

590 Mafic to intermediate eruptive and intrusive activity resumed almost immediately along the

591 Iberville, Glenwood and Osisko dyke complexes and is represented by a complex network of

592 dykes with poorly developed, irregular and wispy margins intruding the felsic deposits of the

593 Glenwood block (Moore et al., 2014). As these intrusions breached the surface, the complex fed 594 extensive overlying mafic to intermediate lavas directly above and to the east and west of the

595 Glenwood block and formed a third caldera floor (Fig. 16f). In the case of the Glenwood dyke 596 complex, it not only fed lavas within the caldera, but also along the flank of the host complex. 
597 The majority of dykes are basaltic but range in composition from basaltic to andesitic. They also 598 exhibit the greatest variation in magmatic affinity; ranging from tholeiitic to calc-alkaline.

599 Several calc-alkaline mafic dykes intruding the facies of the Glenwood block are notably altered 600 by chloritization, carbonatization and epidotization (Moore et al., 2014) and their calc-alkaline 601 magmatic affinity could be a function of alteration. Another possibility is that these dykes are 602 associated with a younger calc-alkaline event higher in the stratigraphy.

603 The Osisko dyke complex was a key conduit throughout the eruptive history of the RPCC, as is 604 evidenced by the polyphase nature of the Lac Noranda pluton, and was again activated during the 605 younger Noranda event (Mueller et al., 2012). The eastern extension of the Osisko dyke 606 complex is associated with the presence of an east-west-trending fault between the northern 607 limit of the Glenwood block and the overlying mafic lavas of the Chadbourne block (Fig. 2). In 608 addition to being a conduit for intermediate to felsic intrusive facies, it also marks the boundary 609 between the second and third floors of the caldera. Cross-cutting relationships show that 610 intrusion occurred following the emplacement of the overlying mafic lavas and is 611 chronologically associated with mafic to intermediate facies forming the upper stratigraphy of 612 the edifice. A quartz-dioritic sample dated at 2702.0 +/- 1.6 Ma suggests its emplacement is 613 relatively contemporaneous but younger than the lavas of the Glenwood block dated at 2702.9 $614+/-1.4 \mathrm{Ma}$ and 2702.2 +/- 3.0 Ma (Mueller et al., 2012). A second date obtained from a mafic615 rich enclave within the Lac Noranda pluton indicates the dyke complex was re-activated during 616 the younger Noranda event (Pearson and Daigneault, 2009; Mueller et al., 2012).

617 5.1.5 Stage Four: Continued Intracaldera Activity and Summital Events 
618 Volcanic extrusive and intrusive facies located to the north of the Osisko dyke complex and 619 south of the Andesite Fault represent a tertiary caldera floor and infilling event following 620 emplacement of the volcanic and intrusive facies of the Glenwood block (Fig. 16f). These 621 extensive mafic to intermediate lavas and intrusions (SIGEOM, 2012) were fed by the Osisko, 622 Iberville and Glenwood dykes and now comprise the volcanic and intrusive facies of the 623 Chadbourne block (Fig. 2). Monecke et al. (2008) report that deposits similar to facies found 624 within the Horne block are found in the Chadbourne block. Therefore, it is inferred that felsic 625 volcanic activity resumed just before the emplacement of the volcanic and intrusive facies of the 626 Horne block and that these facies are in conformable contact with those of the Horne block (Fig. 627 4) and therefore part of the RPCC.

628 Volcanic and intrusive facies of the Horne block comprise the summital facies of the RPCC.

629 Following the extrusion of the mafic to intermediate lavas of the Chadbourne block, several 630 small felsic dome-flow complexes erupted onto a fourth caldera floor and are now exposed as the 631 volcanic and intrusive facies of the Horne block (Fig. 16g). Small-scale pyroclastic eruptions 632 were either associated with these dome-flow complexes or were erupted from parasitic cones 633 along the rim of the complex (Fig. 16h). Localized pyroclastic and parasitic cones are common 634 in the uppermost stratigraphy of several subaqueous calderas as shallowing of the edifice favours 635 increasing explosive activity (Fiske et al., 2001; Geist et al., 2005; Leat et al., 2013).

636 Facies of the Horne block (Fig. 4) are bounded to the north by the Horne Creek Fault (Fig. 1), 637 also separating the assemblage from the Noranda camp. The lack of correlation between the 638 Horne block with the rest of the Noranda camp has been well documented and persists today 639 (Kerr and Gibson, 1993; Gibson et al., 2000; Monecke et al., 2008) and the model presented here 640 sufficiently explains this lack of correlation. The volcanic and intrusive facies of the Noranda 
641 camp are spatially and chronologically different from those to the south of the Horne Creek

642 Fault, which can now be attributed to the existence of two separate caldera complexes.

\section{$643 \quad$ 5.1.6 Caldera Flank Activity}

644 Throughout the aforementioned stages of caldera development, volcanic and intrusive activity

645 both internal to the caldera and along its margins have continuously built the flanks of the RPCC.

646 The volcanic facies of the Evain block are representative of this activity and comprise the

647 western flank of the RPCC. A quartz- and feldspar-phyric massive rhyolite flow sampled by

648 McNicoll et al. (2014) dated using U-Pb geochronological analysis has a reported age of 2700.6

$649+/-0.9 \mathrm{Ma}$ and could be one of the latest eruptive phases of the RPCC. The extent, geometry and 650 organization of facies of the eastern flank is less clear. Deformation is more developed in the 651 eastern portion of the SNSC, as evidenced by the presence of fold axial traces (Fig. 2). This

652 deformations limits the interpretation of events but a significant accumulation of volcanic facies

653 is present (Figs. 2, 4) and it can be inferred that the eastern flank was of a similar extent to that of 654 the western flank.

655 5.2 Depositional Environment of the Rouyn-Pelletier Caldera Complex

656 The protracted history of deformation and associated shortening events within the Abitibi

657 greenstone belt (i.e. Daigneault et al., 2002; Daigneault et al., 2004) prohibits determination of 658 the exact thickness of the volcanic pile that constructed the RPCC. If we use the Stadacona 659 volcaniclastic unit as an approximate marker for the base of the complex, the thickness of the 660 RPCC is a minimum of five kilometres. Accepting that the McPhee and Glenwood dyke 661 complexes represent the bounding faults of the caldera structure, at an average distance of 
662 approximately six kilometres east-west from each other, the base of the RPCC is likely several 663 tens of kilometres in diameter.

664 The continuous presence of pillow lavas indicates facies of the RPCC were emplaced in a 665 submarine setting. With a potential volcanic pile thickness of five kilometres, most facies of the 666 RPCC were emplaced in a deep marine setting. Kerr and Gibson (1993) estimate that deposits of 667 the Horne Mine sequence were emplaced in a submarine setting at a depth of $100-500 \mathrm{~m}$ but 668 could not conclusively estimate water depth. This shallow level emplacement is consistent with 669 pyroclastic activity at caldera complexes in modern arc settings (Fiske et al., 2001; Geist et al., 670 2005; Leat et al., 2013).

671 Subaqueous to emergent volcanoes and calderas in arc settings, along spreading centres and at

672 hotspots are known to cluster and form larger, complex volcanic centres with nested and

673 overlapping structures such as those of the South Sandwich arc (Leat et al., 2013), the Kermadec 674 arc (Wright et al., 2006), the Galapagos archipelago (Geist et al., 2005), the island of Hawaii (i.e. 675 Walker, 1988) and Tamu Massif (Sager et al., 2013). In the context of the Blake River Group, if 676 we assume that exposed plutons represent the eroded cores of ancient volcanic complexes, it is 677 more than plausible that a series of clustered seamounts, volcanoes and calderas existed along 678 the Archean seafloor (Fig. 17). We therefore propose that the volcanic and intrusive facies of the 679 RPCC form a single subaqueous caldera clustered with the Noranda complex inside the host 680 structure of the New Senator Caldera (Fig. 17).

\section{$681 \quad \underline{6.0}$ Conclusions}

682 Subaqueous volcanic and intrusive facies south of the Horne mine sequence in Rouyn-Noranda, 683 Quebec, are characteristic of facies ranging from early seamount construction to those of a well- 
684 established bimodal subaqueous caldera, known as the Rouyn-Pelletier caldera complex.

685 Voluminous lavas and intrusions south and north of the Stadacona volcaniclastic unit are

686 characteristic of pre-caldera and initial caldera-forming volcanic activity. Subsequent faulting

687 and subsidence resulted in a trapdoor-style collapse along the western margin, allowing for the

688 emplacement of ponded lavas. Piecemeal-style faulting continued after ponded lava

689 emplacement, breaking up the caldera floor and establishing pathways for the lavas and

690 intrusions composing the facies of the central and upper facies assemblages. Facies of the Horne

691 block represent some of the final stages of eruptive activity for the RPCC, as the edifice

692 shallowed and volcanic activity transitioned from effusive to explosive phases. The overall

693 thickness of the volcanic pile is a minimum of five kilometres, with a base of up to several tens

694 of kilometres in diameter. The RPCC was one of several seamounts, volcanoes and calderas

695 clustered along the approximately $2702-2700$ Ma Archean seafloor.

696

$\underline{7.0 \text { Acknowledgements }}$

697 This research is a culmination of a Ph.D. thesis by the first author and an honours thesis by the

698 third author. The project was part of a large, regional-scale study conceptualized by the second

699 author and the fifth author, the late Dr. Wulf Mueller. The first author was awarded funding by

700 the Ontario government as part of the Ontario-Quebec Exchange Fellowship, along with the

701 Graduate Student Fellowship Program and the Hugh E. McKinstry Fund from the Society of

702 Economic Geologists. Further funding and technical support was provided to the first author by

703 the CONSOREM (Consortium de recherche en exploration minérale). Start-up and continued

704 funding was awarded to Dr. Mueller through DIVEX (Diversification of Mineral Exploration in

705 Quebec, project SC-33) and NSERC (Natural Sciences and Engineering Research Council of

706 Canada) grants, with additional financial support provided by industrial partners Alexis Minerals 
707 Corporation, Xstrata Copper and Breakwater Resources. Immeasurable field assistance was 708 provided by Pierre Dufour, Vital Pearson, Dr. Patricia Corcoran, Claude Pilote, Mylaine Pilote, 709 Marie-Eve Parr, Nathan Bridge, Meriem Grifi, Dominique Genna, Levin Castillo-Guimond, 710 Jakrapun Khamboonruang, Cheyenne Sica and Lilliana Paoletti. Additionally, the authors would

711 like to thank Pierre Pilote (Ministère de l'Énergie et des Ressources Naturelles du Québec) for 712 perceptive comments and review of early versions of this manuscript.

\section{$\underline{\text { 8.0 References }}$}

715

716

717

718

Aird, H. M., 2008. Petrological and geochemical investigation of Archean mafic lavas from a small area of the Abitibi Greenstone Belt, Canada. H. B.Sc. thesis, School of Geography and Geosciences, University of St. Andrews, St. Andrews, Scotland, 147 p.

Allmendinger, R. W., Cardozo, N.C., and Fisher, D., 2012. Structural Geology Algorithms: Vectors and Tensors, Cambridge University Press, Cambridge, England, 289 p.

Allen, S. R., Fiske, R. S., and Yoshihiko, T., 2010. Effects of water depth on pumice formation in submarine domes at Sumisu, Izu-Bonin arc, western Pacific. Geology, 38: 391-394.

Ayer, J., Amelin, Y., Corfu, F., Kamo, S., Ketchum, J., Kwok, K., and Trowell, N., 2002. Evolution of the southern Abitibi greenstone belt based on $\mathrm{U}-\mathrm{Pb}$ geochronology: autochthonous volcanic construction followed by plutonism, regional deformation and sedimentation. Precambrian Research 115: 63 - 95. 
727 Barrett, T.J., and MacLean, W.H., 1999. Volcanic sequences, lithogeochemistry, and 728 hydrothermal alteration in some bimodal volcanic-associated massive sulphide 729 730 731

Cardozo, N., and Allmendinger, R.W., 2013. Spherical projections with OSXStereonet.

Bear, A.N., and Cas, R.A.F., 2007. The complex facies architecture and emplacement sequence of a Miocene submarine mega-pillow lava flow system, Muriwai, North Island, New Zealand. Journal of Volcanology and Geothermal Research, 160:

Cas, R.A.F., 1992. Submarine volcanism: eruption styles, products and relevance to understanding the host-rock successions to volcanic-hosted massive sulfide deposits. Economic Geology, 87: 511-541.

Cashman, K.V. and Giordano, G., 2014. Calderas and magma reservoirs. Journal of Volcanology and Geothermal Research, 288: 28-45. the Northern Volcanic Zone, Abitibi Belt, Quebec. Canadian Journal of Earth Sciences, 29 (10): 2211-2225. 
746 Corcoran, P.L., 2000. Recognizing distinct portions of seamounts using volcanic facies

747 analysis: examples from the Archean Slave Province, NWT, Canada.

$748 \quad$ Precambrian Research, 101: $237-261$.

749

750

751

752

753

754

755

756

757

758

759

760

761

762

763

764

765

766

767
Daigneault, R., Mueller, W.U., and Chown, E.H., 2002. Oblique Archean subduction: accretion and exhumation of an ocean arc during dextral transpression, Southern Volcanic Zone, Abitibi greenstone belt, Canada. Precambrian Research, 115: 261-290.

Daigneault, R., Mueller, W.U., and Chown, E.H., 2004. Abitibi greenstone belt plate tectonics: the diachronous history of arc development, accretion and collision. In: Eriksson, P.G., Altermann, W., Nelson, D.R., Mueller, W.U., Catuneanu, O. (Eds.), The Precambrian Earth: Tempos and Events, Developments in Precambrian Geology, 12: $89-103$.

Dimroth, E., Cousineau, P., Leduc, M., Sanschagrin, Y., 1978. Structure and organization of Archean subaqueous basalt flows, Rouyn-Noranda area, Quebec, Canada. Canadian Journal of Earth Sciences, 15: 902-918.

Dimroth, E., Imreh, L., Rocheleau, M., and Goulet, N., 1982. Evolution of the south-central part of the Archean Abitibi belt, Quebec. Part I: Stratigraphy and paleogeographic model. Canadian Journal of Earth Sciences, 19: 1729-1758.

Dimroth, E., Rocheleau, M., Boivin, P., Larouche, M., Côté, R., 1974. Stratigraphic and tectonic work on the Rouyn-Noranda area, counties of Rouyn-Noranda, Abitibi-West and Timiskaming. Ministère des Richesses naturelles, Québec, Canada, DP-246, 43 p. 
768 769

770

771

772

773

774

775

776

777

778

779

780

781

782

783

784

785

786

787

788

789

Fiske, R.S., Naka, J., Iizasa, K., Uasa, M., and Klaus, A., 2001. Submarine silicic caldera at the front of the Izu-Bonin arc, Japan: Voluminous seafloor eruptions of rhyolite pumice. Geological Society of America Bulletin, 113: 813-824.

Geist, D.J., Naumann, T.R., Standish, J.J., Kurz, M.D., Harpp, K.S., White, W.M., and Fornari, D.J., 2005. Wolf Volcanic, Galapagos Archipelago: melting and magmatic evolution at the margins of a mantle plume. Journal of Petrology, 46: $2197-2224$.

Genna, D., Gaboury, D., Moore, L., and Mueller, W.U., 2011. Use of micro-XRF chemical analysis for mapping volcanogenic massive sulfide related hydrothermal alteration; application to the subaqueous felsic dome-flow complex of the Cap d'Ours section, Glenwood Rhyolite, Rouyn-Noranda, Quebec, Canada. Journal of Geochemical Exploration, 108: 131-142.

Gibson, H.L., 1989. The mine sequence of the central Noranda volcanic complex: Geology, alteration, massive sulfide deposits and volcanological reconstruction. Ph.D. thesis, Department of Earth Sciences, Carleton University, Ottawa, Ontario, Canada, 715 p.

Gibson, H.L. and Galley, A.G., 2007. Volcanogenic massive sulfide deposits of the Archean Noranda district, Quebec. In: Goodfellow, W.D. (Ed.), Special Publication 5, Mineral Deposits Division, Geological Association of Canada, $533-552$.

Gibson, H.L., and Watkinson, D.H., 1990. Volcanogenic massive sulfide deposits of the Noranda cauldron and shield volcano, Quebec. Canadian Institute of Mining Metallurgy Special Volume, 43: 119-132. 
790 Gibson, H.L., Kerr, D.J., and Cattalani, S., 2000. The Horne mine: geology, history, 791 influence on genetic models, and a comparison to Kidd Creek Mine. Exploration and Mining Geology, 9: 91-111.

793

794

795

796

797

798

799

800

801

802

803

804

805

806

807

808

Goodwin, A.M., 1977. Archean volcanism in Superior Province, Canadian shield. In: Baragar, W.R.A., Coleman, L.C., Hall, J.M. (Eds.), Volcanic Regimes in Canada, Geological Association of Canada, Special Paper 16: 205-241.

Goutier, J., McNicoll, V.J., Dion, C., Lafrance, B., Legault, M., Ross, P.-S., MercierLangevin, P., Cheng, L.Z., de Kemp, E., and Ayer, J., 2009. L'impact du Plan cuivre et de l'IGC-3 sur la géologie de l'Abitibi et du Groupe de Blake River. Ministère des Ressources naturelles et de la Faune (Québec), Rapport GM 64195, 9-13.

Gregg, T.K.P., Fornari, D.J., Perfit, M.R., Ridley, W.I., Kurz, M.D., 2000. Using submarine lava pillars to record mid-ocean ridge eruption dynamics. Earth and Planetary Science Letters, 178: 195-214.

Hannington, M.D., Barrie, C.T., and Bleeker, W., 1999. The Giant Kidd Creek volcanogenic massive sulfide deposit, western Abitibi subprovince, Canada. Economic Geology Monograph, 10: 1-30.

Kerr, D.J., and Gibson, H.L., 1993. A comparison of the Horne volcanogenic massive sulfide deposit and intracauldron deposits of the Mine sequence, Noranda, Quebec. Economic Geology, 88: 1419-1442. 
809 Lachlan-Cope, T., Smellie, J.L., and Ladkin, R., 2001. Discovery of a recurrent lava lake on

810 Saunders Island (South Sandwich Islands) using AVHRR imagery. Journal of

$811 \quad$ Volcanology and Geothermal Research, 112: 105-116.

812 Laurin, J., 2009. Geology, gold mineralization and alteration of the Horne West property

813 Rouyn-Noranda. M. Sc thesis, Department of Earth Sciences, University of

$814 \quad$ Ottawa, Ottawa, Canada, $172 \mathrm{p}$.

815 Leat, P.T., Tate, A.J., Tappin, D.R., Day, S.J., and Owen, M.J., 2010. Growth and mass

816 wasting of volcanic centres in the northern South Sandwich arc, South Atlantic,

817 revealed by new multibeam mapping. Marine Geology, 275: 110-126.

818 Leat, P.T., Day, S.J., Tate, A.J., Martin, T.J., Owen, M.J., and Tappin, D.R., 2013.

819

820

Volcanic evolution of the South Sandwich volcanic arc, South Atlantic, from

multibeam bathymetry. Journal of Volcanology and Geothermal Research, 265, 60-77.

821 Lipman, P.W., 1997. Subsidence of ash-flow calderas: relation to caldera size and

822 magma-chamber geometry. Bulletin of Volcanology, 59: 198-218.

823

824

825

826

827

828

829
Ludden, J.N., Gélinas, L., and Trudel, P., 1982. Archean metavolcanics from the RouynNoranda district, Abitibi greenstone belt, Québec: mobility of trace elements and petrogenetic constraints. Canadian Journal of Earth Science, 19: 2276-2287.

McNicoll, V., Goutier, J., Dubé, B., Mercier-Langevin, P., Ross, P.-S., Dion, C., Monecke, T., Legault, M., Percival, J. and Gibson, H., 2014. U-Pb Geochronology of the Blake River Group, Abitibi Greenstone Belt, Qubec, and Implications for Base Metal Exploration. Economic Geology, 109: 27-59 
830

831

832

833

834

835

836

837

838

839

840

841

842

843

844

845

846

847

848

849

850

McPhie, J., 1995. A Pliocene shoaling basaltic seamount: Ba Volcanic Group at Rakiraki, Fiji. Journal of Volcanology and Geothermal Research, 64: 193210.

Mercier-Langevin, P., Dubé, B., Hannington, M.D., Davis, D.W., Lafrance, B., and Gosselin, G., 2007a. The LaRonde Penna Au-rich volcanogenic massive sulfide deposit, Abitibi greenstone belt, Quebec: Part I. Geology and geochronology. Economic Geology, 102: 585-609.

Mercier-Langevin, P., Dubé, B., Hannington, M.D., Richer-Laflèche, M., and Gosselin, G., 2007b. The LaRonde Penna Au-rich volcanogenic massive sulphide deposit, Abitibi greenstone belt, Quebec: Part II. Lithogeochemistry and paleotectonic setting. Economic Geology, 102: 611-631.

Monecke, T., Gibson, H.L., Dubé, B., Laurin, J., Hannington, M.D., and Martin, L., 2008. Geology and volcanic setting of the Horne deposit, Rouyn-Noranda, Quebec: initial results of a new research project. Geological Survey of Canada, Current Research 2008-9, 16 p.

Moore, L.N., Mueller, W.U., and Daigneault, R., 2012. In situ hydroclastic fragmentation of subaqueous ponded lavas; New Senator caldera, Abitibi greenstone belt, Québec, Canada. Precambrian Research, 214-215: 44-59.

Moore, L.N., Daigneault, R., Genna, D., Hollings, P., and Mueller, W.U., 2014. Exogenous and endogenous construction of the subaqueous Glenwood felsic lava flow complex; Abitibi greenstone belt, Québec, Canada. Precambrian Research, 251: 118-140. 
851 Morton, R.L., Walker, J.S., Hudak, G.J., and Franklin, J.M., 1991. The early development of an 852 Archean submarine caldera complex with emphasis on the Mattabi ash-flow tuff and its 853 relationship to the Mattabi massive sulfide deposit. Economic Geology, 86: 1002-1011.

854

855

856

857

858

859

860

861

862

863

864

865

866

867

868

869

870

871

Mueller, W.U., Stix, J., Corcoran, P.L., and Daigneault, R., 2009. Subaqueous calderas in the Archean Abitibi greenstone belt: an overview and new ideas. Ore Geology Reviews, 35: 4-46.

Mueller, W.U., Friedman, R., Daigneault, R., Moore, L., and Mortensen, J., 2012. Timing and characteristics of the Archean subaqueous Blake River Megacaldera Complex, Abitibi greenstone belt, Canada. Precambrian Research, 214-215: 1-27.

Mueller, W.U., Stix, J., Corcoran, P.L., and Daigneault, R., Subaqueous calderas in the Archean Abitibi greenstone belt: An overview and new ideas. Ore Geology Reviews, 35: 4-46.

Pearson, V., and Daigneault, R., 2009. An Archean megacaldera complex: The Blake River Group, Abitibi greenstone belt. Precambrian Research, 168: 66-82.

Péloquin, A.S., and Piercey, S.J., 2008. The Ben Nevis Volcanic Complex, Ontario, Canada: Part of the Late Volcanic Phase of the Blake River Group, Abitibi Subprovince. Economic Geology, 103: 1219-1241.

Powell, W.G., Carmichael, D.M., and Hodgson, C.J., 1995. Conditions and timing of metamorphism in the Southern Abitibi greenstone belt. Canadian Journal of Earth Sciences, 32: 787-805.

Ross, P.-S., Goutier, J., Mercier-Langevin, P., and Dubé, B., 2011 a. Basaltic to andesitic volcaniclastic rocks in the Blake River Group, Abitibi greenstone 
872

873

874

875

876

877

878

879

880

881

882

883

884

885

886

887

888

889

890

891

892

belt: 1. Mode of emplacement in three areas. Canadian Journal of Earth Sciences, 48: 728-756.

Ross, P.-S., McNicoll, V., Goutier, J., Mercier-Langevin, P., and Dubé, B., 2011 b. Basaltic to andesitic volcaniclastic rocks in the Blake River Group, Abitibi greenstone belt: 2 . Origin, geochemistry, and geochronology. Canadian Journal of Earth Sciences, 48: 757-777.

Ross, P.-S., Goutier, J., Percival, J.A., Mercier-Langevin, P., and Dubé, B., 2008. New volcanological and geochemical observations from the Blake River Group, Abitibi greenstone belt, Quebec: the D'Alembert tuff, the Stadacona unit, and surrounding lavas. Geological Survey of Canada, Current Research, 2008-17, $27 \mathrm{p}$.

Sager, W.W., Zhang, J., Korenaga, J., Sano, T., Koppers, A.A.P., Widdowson, M., and Mahoney, J.J., 2013. An immense shield volcano within the Shatsky Rise oceanic plateau, northwest Pacific Ocean. Nature Geoscience, 6: 976-981.

SIGEOM 2012, Système d'information géominière du Québec, ministère de l'Énergie et des Ressources du Québec, Public database version 2012.

Sterckx, S., Ross, P.-S., and Goutier, J., 2013. Géochimie des roches volcaniques archéennes du Groupe de Blake River, Sous-province de l'Abitibi, Québec : rapport préliminaire. Ministère des Ressources naturelles, Québec; report MB 2013-09, 21 p.

Sterckx, S., Ross, P.-S., and Goutier, J., 2014. Géochimie des roches volcaniques archéennes du Groupe de Blake River, Sous-province de l'Abitibi, Québec : composition des 
893

894

895

896

897

898

899

900

901

902

903

904

905

906

907

908

909

910

911

échantillons « frais ». Ministère de l'Énergie et des Ressources naturelles, Québec; report MB-2014-32, 22 p.

Sun, S.S., and McDonough, W.F., 1989. Chemical and isotopic systematics of oceanic basalts: implications for mantle composition and processes. In: Fitton, J.G., Upton, B.G.J. (Eds.), Magmatism in the Ocean Basins. Geological Society of America, Special Publication, 42: 399-444.

Tani, K., Fiske, R.S., Tamura, Y., Kido, Y., Naka, J., Shukuno, H., and Takeuchi, R., 2008. Sumisu volcano, Izu-Bonin arc, Japan: site of a silicic caldera-forming eruption from a small open-ocean island. Bulletin of Volcanology, 70 : 547-562.

Thurston, P.C., Ayer, J.A., Goutier, J., and Hamilton, M.A., 2008. Depositional Gaps in Abitibi Greenstone Belt Stratigraphy: A Key to Exploration for Syngenetic Mineralization. Economic Geology, 103: 1097-1134.

Walker, G.P.L., 1988. Three Hawaiian calderas: an origin through loading by shallow intrusions? Journal of Geophysical Research, 93: 14773-14784.

Wilson, M.E., 1941. Noranda district, Québec. Geological Survey of Canada Memoir 29, Ottawa, Canada, $162 \mathrm{p}$.

Winchester, J.A., and Floyd, P.A., 1977. Geochemical discrimination of different magma series and their differentiation products using immobile elements. Chemical Geology, 20 (4): 325-343. 
912 Wright, I.C., and Gamble, J.A., 1999. Southern Kermadec submarine caldera arc volcanoes

913 (SW Pacific): caldera formation by effusive and pyroclastic eruption. Marine Geology, 914 161: 207-227.

915 Wright, I.C., Stoffers, P., Hannington, M., de Ronde, C.E.J., Herzig, P., Smith, I.E.M., 916 and Browne, P.R.L., 2002. Towed-camera investigations of shallow-intermediate 917 water-depth submarine stratovolcanoes of the southern Kermadec arc, New 918 Zealand. Marine Geology, 185: 207-218.

919 Wright, I.C., Worthington, T.J., and Gamble, J.A., 2006. New multibeam mapping and 920 geochemistry of the $30^{\circ}-35^{\circ} \mathrm{S}$ sector, and overview, of southern Kermadec arc volcanism. Journal of Volcanology and Geothermal Research, 149:

922 263-296. 


\subsection{Table 1}

\begin{tabular}{|c|c|c|c|c|}
\hline Block Name & Facies & Volcanic Textures and Features & Petrography & Process and Setting \\
\hline \multirow{4}{*}{ Pelletier Block } & $\begin{array}{l}\text { Pillowed } \\
\text { Lava Flows }\end{array}$ & $\begin{array}{l}\text { Flows range in thickness from }<0.5 \mathrm{~m} \text { to } 18 \mathrm{~m} \text {. } \\
\text { Individual pillows have horizontal and vertical axes } \\
\text { ranging from cm- to m-scale. } \\
\text { Forms are rounded to elongated and keel structures } \\
\text { show younging direction to the north. }\end{array}$ & $\begin{array}{l}\text { Aphanitic groundmass with } \\
\text { occasional porphyritic texture with } \\
\text { relict plagioclase and chlorite; } \\
\text { amygdules rimmed/filled with quartz, } \\
\text { carbonate, zeolite and/or epidote }\end{array}$ & $\begin{array}{l}\text { Low-energy effusive } \\
\text { mafic lava flows typical } \\
\text { of seamount construction }\end{array}$ \\
\hline & $\begin{array}{l}\text { Massive } \\
\text { Lava Flows }\end{array}$ & $\begin{array}{l}\text { Flows range in thickness from }<10 \mathrm{~cm} \text { to } 7 \text { metres. } \\
\text { Most flows are massive but transition laterally into } \\
\text { lobate and pillowed flows. } \\
\text { Internally brecciated and brecciated at margins. } \\
\text { Brecciated margins are }<10 \mathrm{~cm} \text { to } 5 \mathrm{~m} \text { thick and } \\
\text { contain hyaloclastite, rip-ups and pillow rinds; } \\
\text { weathered bright orange in the field. }\end{array}$ & $\begin{array}{l}\text { Dominantly aphanitic groundmass; } \\
\text { epidote, carbonate, chlorite, actinolite } \\
\text { and relict feldspar present; some } \\
\text { amygdules present filled with quartz } \\
\text { and/or carbonate, minor epidote } \\
\text { present. }\end{array}$ & $\begin{array}{l}\text { Low to moderate energy } \\
\text { mafic lava flows typical } \\
\text { of initial seamount } \\
\text { construction }\end{array}$ \\
\hline & Mafic Sills & $\begin{array}{l}5-35 \mathrm{~m} \text { thick, fine to medium grained, massive to } \\
\text { layered }(5-10 \mathrm{~cm} \text { thick feldspar- and mafic-rich } \\
\text { layers), well developed chilled margins. }\end{array}$ & $\begin{array}{l}\text { Dominantly epidote, albite, chlorite, } \\
\text { actinolite and muscovite; accessory } \\
\text { carbonate, quartz, titanite and oxides }\end{array}$ & $\begin{array}{l}\text { Mafic intrusions } \\
\text { characteristic of inflation } \\
\text { of mafic volcanic edifices }\end{array}$ \\
\hline & Mafic Dykes & $\begin{array}{l}\mathrm{Cm} \text { - to m-scale, taper and anastomose laterally, } \\
\text { wispy terminations with dismembered morphology. }\end{array}$ & $\begin{array}{l}\text { Aphanitic to fine grained with } \\
\text { unidentifiable mafic minerals and } \\
\text { feldspar; glomerocrystic plagioclase } \\
\text { texture with epidote replacement; } \\
\text { epidote, chlorite, actinolite, albite and } \\
\text { carbonate present in groundmass; } \\
\text { quartz and epidote visible as patchy } \\
\text { alteration. }\end{array}$ & $\begin{array}{l}\text { Synvolcanic intrusions } \\
\text { discordant to volcanic } \\
\text { facies; intrude along } \\
\text { fractures during inflation } \\
\text { events and feed upper } \\
\text { level flows when surface } \\
\text { breached }\end{array}$ \\
\hline
\end{tabular}




\begin{tabular}{|c|c|c|c|c|}
\hline Block Name & Facies & Volcanic Textures and Features & Petrography & Process and Setting \\
\hline \multirow{5}{*}{ Senator Block } & $\begin{array}{l}\text { Ponded } \\
\text { massive } \\
\text { lavas }\end{array}$ & $\begin{array}{l}\text { Range in thickness from } 2.5 \text { to } 30 \mathrm{~m} \text { with most } \\
\text { being }<5 \mathrm{~m} \text { thick } \\
\text { Mostly aphanitic to fine grained with thickest units } \\
\text { up to sub-ophitic. } \\
\text { Bounded by hyaloclastite-rich horizons. } \\
\text { Variolitic texture visible along contacts with } \\
\text { hyaloclastite horizons }\end{array}$ & $\begin{array}{l}\text { Relict pyroxene and feldspars present } \\
\text { but rare; dominantly actinolite and } \\
\text { chlorite phases present with minor } \\
\text { quartz, carbonate, oxide phases and } \\
\text { epidote present. Variolites are } \\
\text { individual and clustered }\end{array}$ & $\begin{array}{l}\text { Voluminous low-energy } \\
\text { effusive events; lava } \\
\text { collects in synvolcanic } \\
\text { depressions or sag } \\
\text { structures }\end{array}$ \\
\hline & $\begin{array}{l}\text { Hyaloclastite } \\
\text { Horizons }\end{array}$ & $\begin{array}{l}\text { Aphanitic. Fragments are } \mathrm{mm} \text { - to } \mathrm{cm} \text {-scale with } \\
\text { angular and polycuspate forms that weather orange- } \\
\text { beige in the field. } \\
\text { Pillowed forms, cigar structures and v-shaped } \\
\text { structures found entrained within the horizons. } \\
\text { cm-scale blocky tabular jointing found internal to } \\
\text { pillowed forms. }\end{array}$ & $\begin{array}{l}\text { Micro-crystalline to aphanitic in thin } \\
\text { section. Individual mineral phases in } \\
\text { groundmass not identifiable in thin } \\
\text { section. Individual and clustered } \\
\text { variolites contain relict feldspar and } \\
\text { chlorite. Perlitic fractures are visible } \\
\text { in larger fragments. }\end{array}$ & $\begin{array}{l}\text { Small-scale in situ } \\
\text { fragmentation within } \\
\text { ponded lavas. Occurs as } \\
\text { water/steam propagates } \\
\text { along fractures. }\end{array}$ \\
\hline & $\begin{array}{l}\text { Mafic Dykes } \\
\text { and Sills }\end{array}$ & $\begin{array}{l}\text { Dykes are aphantic to fine grained, whereas sills } \\
\text { can be medium grained with ophitic texture. } \\
\text { Dykes have sharp but irregular chilled margins. } \\
\text { Visibly altered and vesiculated in the field. }\end{array}$ & $\begin{array}{l}\text { Chlorite is the dominant mineral } \\
\text { phase in all thin sections, with } \\
\text { actinolite, carbonate, sericite, epidote, } \\
\text { quartz and feldspar also visible. Both } \\
\text { feldspar and pyroxene present as } \\
\text { relict phases. Minor oxides and } \\
\text { sulfides in most samples. }\end{array}$ & $\begin{array}{l}\text { Synvolcanic intrusions } \\
\text { associated with inflation of } \\
\text { the edifice; intrude along } \\
\text { discordant fractures and } \\
\text { concordant stratigraphic } \\
\text { boundaries. }\end{array}$ \\
\hline & $\begin{array}{l}\text { Pillowed } \\
\text { Lava Flows }\end{array}$ & $\begin{array}{l}\text { Exact thickness unknown; one unit ranges from } 10 \\
\text { to } 12 \mathrm{~m} \text { thick. Pillows are undeformed (rounded to } \\
\text { ovoid) to deformed (molar tooth and boomerang } \\
\text { forms) and can be up to a metre in diameter. } \\
\text { Flows are vesiculated and vesicle morphology } \\
\text { reflects level of deformation - from } \\
\text { rounded/elongated to flattened. } \\
\text { Hyaloclastite fragments occur at pillow margins } \\
\text { and in cavities between pillows. }\end{array}$ & $\begin{array}{l}\text { Chlorite is the dominant mineral } \\
\text { phase with actinolite, feldspar, quartz, } \\
\text { epidote and minor oxides comprising } \\
\text { the groundmass. Vesicles visible as } \\
\text { voids or filled with phyllosilicate } \\
\text { and/or alteration phases. Individual } \\
\text { and clustered variolites present. }\end{array}$ & $\begin{array}{l}\text { Low-energy flows } \\
\text { breaching along margins of } \\
\text { massive ponded lavas and } \\
\text { beginning to flow floor. }\end{array}$ \\
\hline & $\begin{array}{l}\text { Massive } \\
\text { Lava Flows }\end{array}$ & $\begin{array}{l}\text { Thickness of flows ranges from }<5 \text { to } 20 \mathrm{~m} \text {. Flows } \\
\text { are aphanitic to fine grained and vesiculated. cm- } \\
\text { to m-scale lobate structures present along southern } \\
\text { margins. }\end{array}$ & $\begin{array}{l}\text { Chlorite is the dominant mineral } \\
\text { phase with actinolite, feldspar, quartz, } \\
\text { epidote and minor oxides comprising } \\
\text { the groundmass. Vesicles visible as } \\
\text { voids or filled with phyllosilicate } \\
\text { and/or alteration phases. }\end{array}$ & $\begin{array}{l}\text { Flows breaching along } \\
\text { margins of massive ponded } \\
\text { lavas and flowing along the } \\
\text { caldera floor. Massive } \\
\text { flows are higher volume } \\
\text { and velocity in comparison } \\
\text { to pillowed flows. }\end{array}$ \\
\hline
\end{tabular}




\begin{tabular}{|c|c|c|c|c|}
\hline Block Name & Facies & Volcanic Textures and Features & Petrography & Process and Setting \\
\hline \multirow{3}{*}{$\begin{array}{l}\text { Glenwood } \\
\text { Block }\end{array}$} & $\begin{array}{l}\text { Exogenous } \\
\text { Lava Flows }\end{array}$ & $\begin{array}{l}\text { Exposed thickness of facies ranges from }<50 \mathrm{~m} \text { to } ~ \\
200 \mathrm{~m} \text {. Stacked flows transition laterally from } \\
\text { massive to flow and flow-front breccia. } \\
\text { Lobes, detached lobes, columnar joints and flow } \\
\text { banding present. Brecciated fragments are sub- } \\
\text { rounded to angular and exhibit jigsaw textures } \\
\text { locally. }\end{array}$ & $\begin{array}{l}\text { All facies are aphanitic; groundmass } \\
\text { (where visible) dominated by quartz } \\
\text { and feldspar phenocrysts with minor } \\
\text { chlorite and biotite. } \\
\text { Chlorite present as alteration phase, } \\
\text { as is sericite and quartz. Perlitic } \\
\text { fractures present in massive facies } \\
\text { and in breccia fragments }\end{array}$ & $\begin{array}{l}\text { Structurally-controlled low- } \\
\text { energy felsic lava flows; } \\
\text { flow west to east along } \\
\text { caldera floor. Effusive } \\
\text { eruption with associated } \\
\text { autoclastic brecciation. }\end{array}$ \\
\hline & $\begin{array}{l}\text { Endogenous } \\
\text { Lobes }\end{array}$ & $\begin{array}{l}\text { Mostly massive quartz- and feldspar-phyric lobes } \\
\text { confined to brecciated exogenous facies. Some } \\
\text { brecciation at upper levels and along margins. }\end{array}$ & $\begin{array}{l}\text { Aphanitic to fine grained groundmass } \\
\text { with large, porphyritic feldspar and } \\
\text { quartz phenocrysts. Weak to } \\
\text { moderate sericitization with weak } \\
\text { chloritization. }\end{array}$ & $\begin{array}{l}\text { Structurally controlled; } \\
\text { intrude exogenous flows but } \\
\text { breach surface and begin to } \\
\text { brecciate; last stage of felsic } \\
\text { volcanism }\end{array}$ \\
\hline & Mafic Dykes & $\begin{array}{l}\mathrm{cm} \text { - to m-scale, vary from well defined chilled } \\
\text { margins to irregular, wispy margins; some } \\
\text { vesiculated; concordant to discordant }\end{array}$ & $\begin{array}{l}\text { Aphanitic to sub-ophitic textured; } \\
\text { dominantly chlorite, actinolite, } \\
\text { epidote, feldspar and quartz with } \\
\text { oxide phases; alteration phases } \\
\text { present as epidote, chlorite, carbonate } \\
\text { and quartz; vesicles visible in thin } \\
\text { section and filled with carbonate, } \\
\text { epidote and/or quartz }\end{array}$ & $\begin{array}{l}\text { Dykes fed by larger dyke } \\
\text { complexes (the Glenwood, } \\
\text { Osisko and Iberville Dyke } \\
\text { Complexes), concordant } \\
\text { dykes intruded along } \\
\text { stratigraphic contacts; } \\
\text { discordant dykes intruded } \\
\text { along synvolcanic fractures; } \\
\text { associated with inflation } \\
\text { and subsidence events. }\end{array}$ \\
\hline
\end{tabular}




\section{$\underline{10.0}$ Figure Captions}

Figure 1. Blake River Megacaldera Complex. Synvolcanic faults and distribution of volcanic and intrusive facies delineate the host Misema caldera and nested New Senator (in purple) and Noranda calderas. The New Senator Caldera is further divided into three sectors (northwest, central and southeast) by the Hunter Creek Fault (HuCF) and the Horne Creek Fault (HoCF) respectively. $(\mathrm{MDF}=\mathrm{McDougall}-\mathrm{Depsina}$ Fault; $\mathrm{TSF}=\mathrm{T} . \mathrm{S}$. Fault; $\mathrm{PF}=$ Pink Fault; $\mathrm{ABCF}=$ $\mathrm{ABC}$ Fault; $\mathrm{BF}=$ Beauchastel Fault; $\mathrm{EFVC}=$ Évain Felsic Volcanic Complex). Inset shows the regional map of the Abitibi greenstone belt within the province of Quebec, Canada with domain and stratigraphic divisions $(\mathrm{NVZ}=$ Northern Volcanic Zone; SVZ = Southern Volcanic Zone; $\mathrm{BRG}=$ Blake River Group; $=\mathrm{PP}=$ Pontiac Sub-province; GP = Grenville Province; DPMFZ = Destor Porcupine-Manneville Fault Zone; CLLFZ = Cadillac-Larder Lake Fault Zone) (modified from Pearson and Daigneault, 2009; Moore et al., 2014).

Figure 2. General geology, synvolcanic structures, distribution of volcanic facies and notable features of the southern Rouyn-Noranda region (modified from Moore et al., 2012).

Figure 3. Measured values of the regional schistosity (black) showing a global E-W trend with a sub-vertical stretching lineation (red) (plotted on an equal area stereonet using Stereonet 8; Allmendinger et al., 2012; Cardozo and Allmendinger, 2013. B) $\mathrm{S}_{0}$ values measured at Locality A showing dispersion along a great circle defining a fold axis plunging 45 degrees to the east (pole indicated in red) (plotted on an equal area stereonet using Stereonet 8; Allmendinger et al., 2012; Cardozo and Allmendinger, 2013). C) Folded massive and pillowed mafic lava flows of Locality A showing a fold axial trace consistent with a synclinal structure. 
Figure 4. Facies assemblages of the Rouyn-Pelletier Caldera Complex. Distribution and boundaries of facies assemblages are shown in relation to the geology of the southern RouynNoranda region, along with outcrops and other locations within the study area (modified from Moore et al., 2012; Moore et al., 2014).

Figure 5. Post- and -pre-ductile deformation model of the Rouyn-Pelletier sector (RPS). A) Post-ductile deformation organization of major structural elements (faults and dykes) within the RPS. B) Interpretive reconstruction of pre-ductile deformation geometry depicting an accumulation of strain in the eastern region of the RPS.

Figure 6. Schematic stratigraphic sections depicting dominant facies of each block of the Rouyn-Pelletier sector. Information for facies of the Évain, Stadacona, Chadbourne and Horne blocks obtained from: SIGEOM, 2012; McNicoll et al., 2014; Ross et al., 2008; Monecke et al., 2008; Laurin, 2009.

Figure 7. Locality 1. Mafic flows and sills and felsic volcaniclastic deposits of the Pelletier block with relevant photo positions represented by red boxes (modified from Aird, 2008).

Figure 8. Locality 2. Massive, pillowed and lobate mafic flows with brecciated margins of the Pelletier block with relevant photo positions shown with white and black boxes.

Figure 9. Mafic extrusive and intrusive facies of the Pelletier block. A) Closely packed pillows at Locality 1 (grid is approximately 1 metre wide by 1.5 metres long). B) In situ brecciated (Ib) massive flow at Locality 2 with mm-scale hyaloclastite fragments hosted within fractures (hammer is approximately $35 \mathrm{~cm}$ long). C) Columnar jointing $(\mathrm{Cj})$ in a massive mafic flow at Locality 2 (scale card is $8 \mathrm{~cm}$ long). D) Brecciated flow margin of massive mafic flow with iron-stained, hyaloclastite-rich (Hy) matrix (grid markers at left margin of photo are spaced 20 
$\mathrm{cm}$ apart; Locality 2). E) Pillow fragments (Pf) and pillow rinds (Pr) in a hyaloclastite-rich matrix at the margin of a massive mafic flow (grid markers are spaced $20 \mathrm{~cm}$ apart; Locality 2). F) Alternating felsic-rich $(\mathrm{Fb})$ and mafic-rich $(\mathrm{Mb})$ bands in a massive mafic sill at Locality 1(hammer is $30 \mathrm{~cm}$ long). G) Felsic volcaniclastic deposits (Fv) within pillowed flows (Pl) at Locality 1 (hammer is $33 \mathrm{~cm}$ long). H) Mafic dyke (Md) with wispy terminations intruding mafic sill (Ms) at Locality 1 (pencil is $14 \mathrm{~cm}$ long).

Figure 10. Mafic extrusive and intrusive facies of the Senator block. A) Sub-ophitic texture in thick massive ponded lava unit at Locality 3 (hammer is $30 \mathrm{~cm}$ long). B) Variolites (Va) at margin of massive ponded lava near a contact with a hyaloclastite horizon at Locality 3 . C) Cigar structures (Cs) hosted within a hyaloclastite horizon at Locality 4 (notebook is $17 \mathrm{~cm}$ long). D) Rounded to ovoid pillowed forms (Pf) in within a hyaloclastite horizon at Locality 4 (notebook is $17 \mathrm{~cm}$ long). E) Lobate forms (Lf) in massive mafic flows exposed at Locality 6 (scale card is $14 \mathrm{~cm}$ long). F) Stretched and elongated deformed pillows in a mafic flow exposed at Locality 6 (scale card is $14 \mathrm{~cm}$ long).

Figure 11. Alternating mafic pillowed and massive flows at the margin of Senator block (Locality 6). Elongated pillow lavas and lobate forms in massive lava flows exemplify increasing deformation approaching the CLLFZ at the southern margin of the study area. Magnified areas 1 to 7 show varying pillow lava morphology throughout the mapped area.

Figure 12. Felsic extrusive and intrusive facies of the Glenwood block. A) Detached lobes (Dl) and $\mathrm{mm}$ - to cm-scale flow banding in the massive lobate facies at Locality 7 (notebook is $17 \mathrm{~cm}$ long). B) Well-developed, cm-scale flow banding (black outline) and sparse fragments (white outline) in the in situ brecciated facies at Locality 7 (scale card is $8 \mathrm{~cm}$ long). C) Millimetre to 
centimetre-scale, sub-angular to angular fragments in glassy matrix, characteristic of the flow breccia facies exposed at Locality 7 (scale card is $8 \mathrm{~cm}$ long). D) Sub-rounded to rounded fragments with near jigsaw-fit texture found within the flow front breccia facies at Locality 7 (lens cap is $7.2 \mathrm{~cm}$ in diameter). E) Locally brecciated margin (yellow outline) of the quartzand feldspar-phyric endogenous lobe facies exposed at Locality 7 (scale card is $8 \mathrm{~cm}$ long). F) Phaneritic texture in the quartz dioritic to tonalitic Lac Noranda pluton (scale card is $8 \mathrm{~cm}$ long; Locality 8). G) Well-developed jointing in an east-west-trending mafic dyke cross-cutting the Lac Noranda pluton (scale card is $8 \mathrm{~cm}$ long; Locality 8 ). Jointing is both parallel to the dyke margins and the regional schistosity. H) Dismembered mafic dyke with wispy terminations intruding the felsic flow breccia facies at Locality 7 (pencil is $14 \mathrm{~cm}$ long).

Figure 13. Lac Noranda pluton (Locality 8) of the Osisko dyke complex. Pluton composition ranges from quartz diorite to tonalite and has an overall phaneritic texture. Several mafic and felsic dykes cross-cut the pluton and trend ESE-WNW. A number of hydrothermally altered zones also cross-cut the pluton and are near-parallel to the orientation of the dykes.

Figure 14. Discrimination and magmatic affinity diagrams for analyzed samples from mafic to felsic extrusive and intrusive volcanic facies of the RPCC. A) Trace element discrimination diagram (Winchester and Floyd, 1977) for extrusive mafic volcanic facies. B) Binary Y vs. Zr magmatic affinity diagram (Barrett and MacLean, 1999) for extrusive mafic volcanic facies. C) Intrusive mafic facies plotted on the trace element discrimination diagram of Winchester and Floyd (1977). D) Extrusive mafic facies of the RPCC plotted on the Y vs. Zr magmatic affinity diagram of Barrett and MacLean (1999). E) Samples from extrusive felsic facies of the RPCC and the Horne Mine (Laurin, 2009) plotted on the trace element discrimination diagram of Winchester and Floyd (1977). F) Binary Yb vs. Th magmatic affinity diagram (Barrett and 
MacLean, 1999) with plotted samples from the extrusive felsic facies of the RPCC and Horne Mine (Laurin, 2009).

Figure 15. Rare earth element plots for analyzed samples from extrusive and intrusive volcanic facies of the RPCC. A) Primitive mantle-normalized REE diagram of mafic extrusive facies with normalization values from Sun and McDonough (1989). B) Samples of mafic intrusive facies of the RPCC plotted with primitive mantle-normalized REE values. C) Primitive mantlenormalized REE profiles of samples from extrusive and intrusive facies of the RPCC.

Figure 16. Evolution of the Rouyn-Pelletier caldera complex. A) Initial mafic seamount development dominated by eruption of pillowed and massive mafic flows (pre-caldera stage; Stadacona block). B) Continued growth of edifice coupled with localized extension beneath it results in the beginning of subsidence, formation of first crater floor and deposition of initial Pelletier block facies and development of bounding faults (marked by McPhee and Glenwood dyke complexes). Mafic lavas begin to fill the crater and construct the floor, completing the formation of the Pelletier block facies (Stage 1). C) Continued asymmetric subsidence and evacuation of magma from underlying chamber causes the formation of a trapdoor caldera geometry and extension of the McPhee fault. D) Elongation of the McPhee fault forms an efficient pathway for lava to travel along the fault and fill in the trapdoor structure with ponded lavas, massive flows and pillowed flows, forming the facies of the Senator block (Stage 2). E) Further faulting of caldera floor results in destruction of original trapdoor geometry and formation of a near-piecemeal geometry, establishing the Glenwood fault. F) The first episode of felsic volcanism is represented by the Glenwood felsic flow complex. Mafic volcanism resumes directly following felsic activity, forming several mafic dyke complexes and intruding the Glenwood complex (Stage 3). Synvolcanic faults allow the mafic lavas to breach the felsic 
deposits, forming the next caldera floor and the deposits of the Chadbourne block (beginning of Stage 4). G) Small intermediate to felsic dome-flow complexes begin to form within crater following the cessation of mafic volcanism, forming the initial facies of the Horne block. H) Intermediate to felsic activity continues and the caldera has evolved to the point where activity becomes more explosive with pyroclastic material begins to accumulate within the crater (end of Stage 4).

Figure 17. Schematic block diagram positioning the RPCC in relation to other volcanic centres of the Blake River Group. The RPCC was clustered on the Archean seafloor with several calderas, volcanoes and seamounts, the cores of which are now exposed as synvolcanic plutons. These clustered volcanic centres formed the majority of the Blake River Group. 
Canadian Journal of Earth Sciences

Page 54 of 70

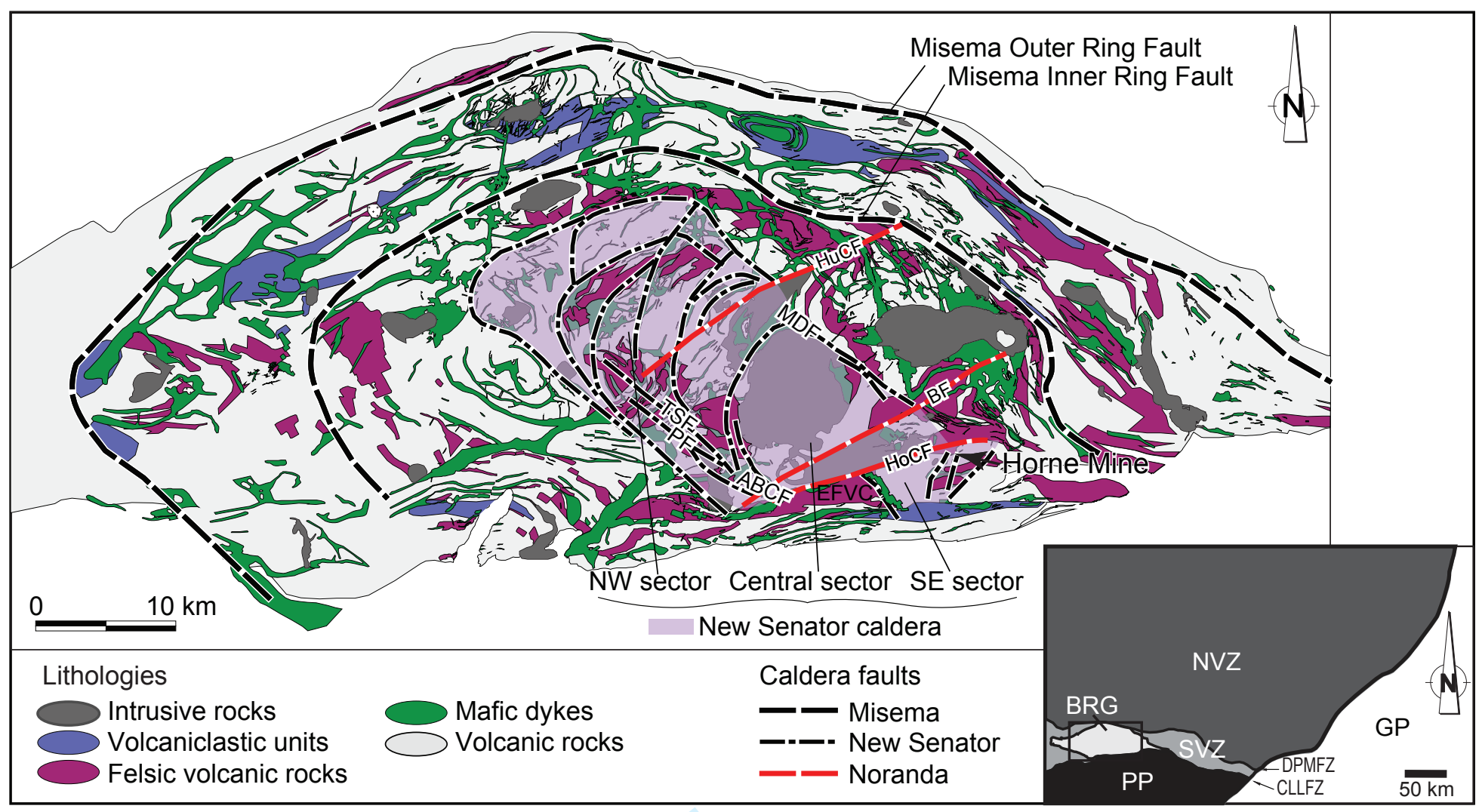

https://mc06.manuscriptcentral.com/cjes-pubs 


\section{Page 55649900 \\ crat59g an dournal of Farth Sciences 650000}

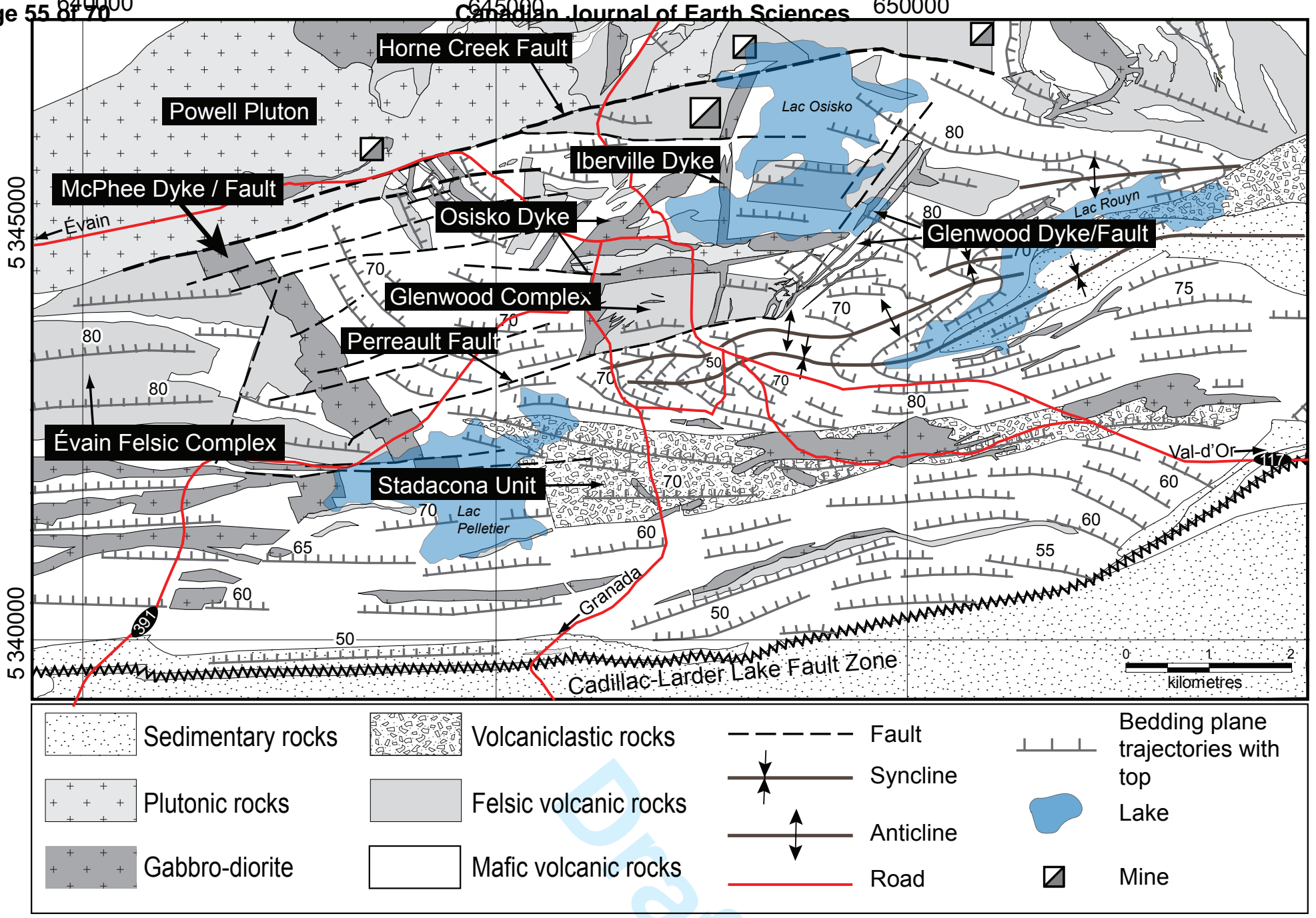




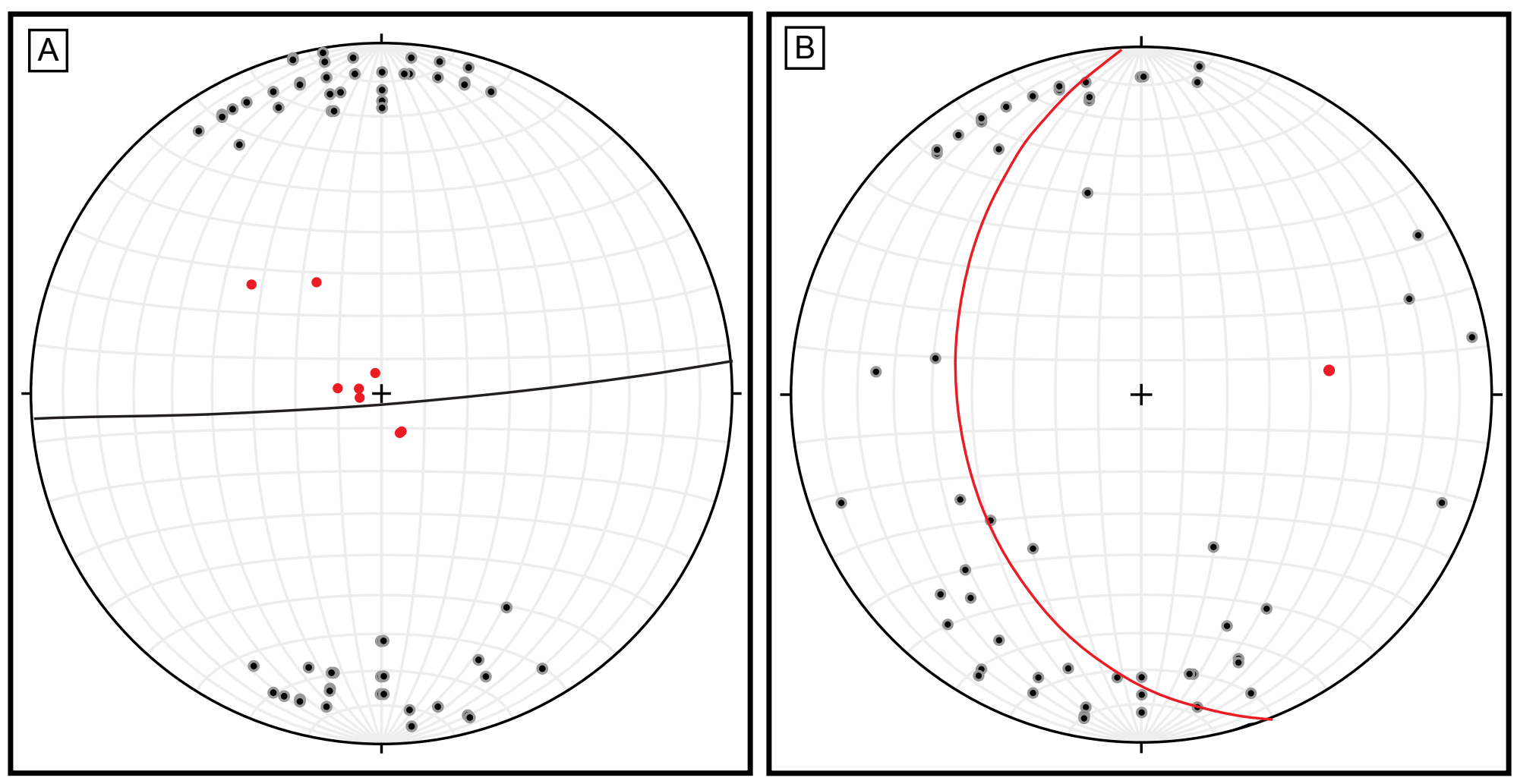

C

1647600

647800
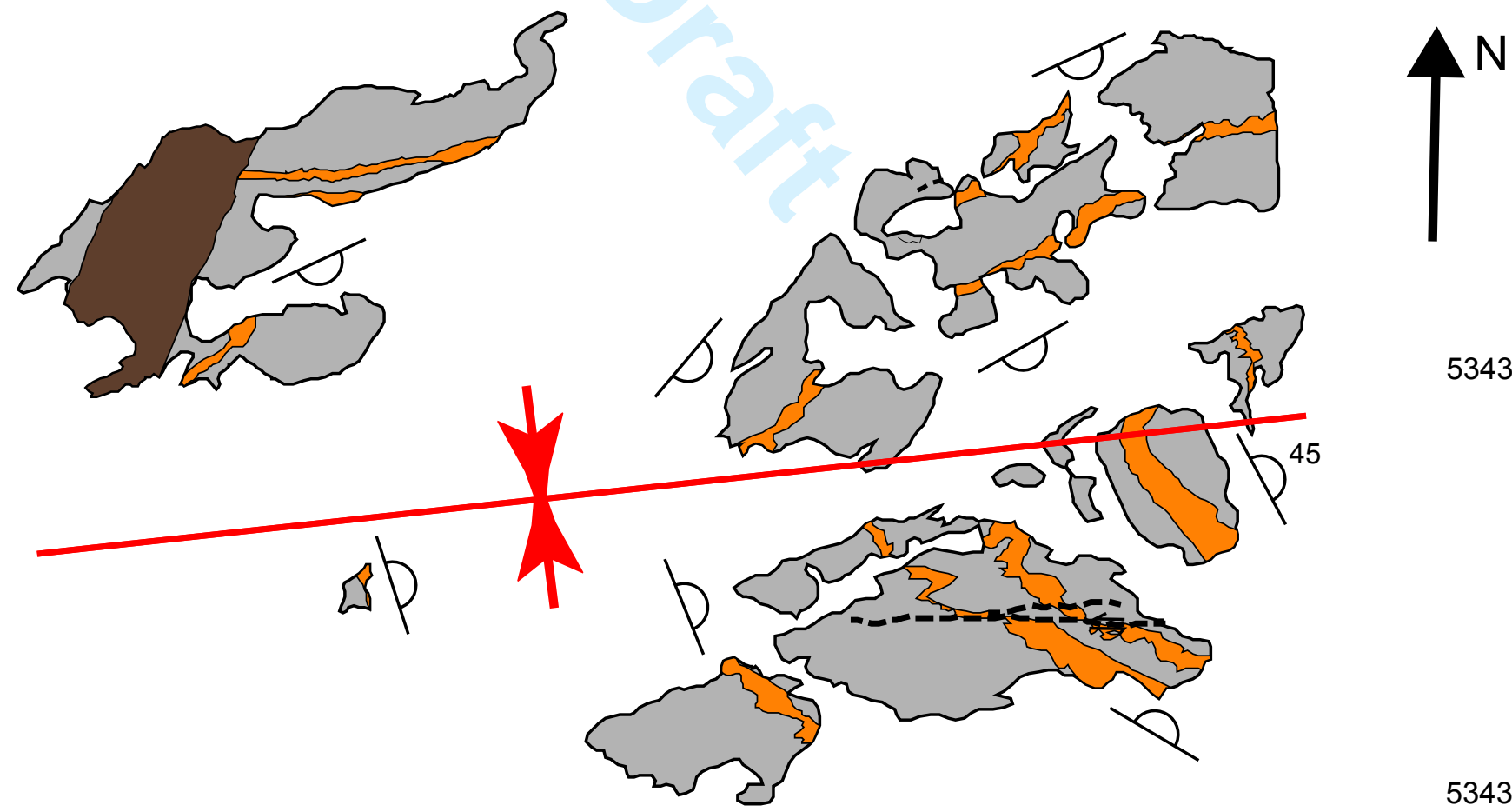

\section{Legend}

Massive and

pillowed basalt

Flow breccia

Mafic dyke

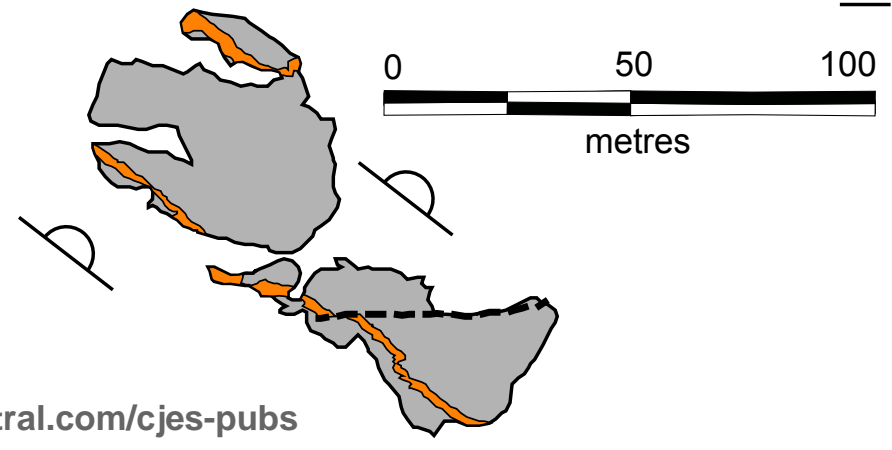


Page 57 of 70

Canadian Journal of Earth Sciences

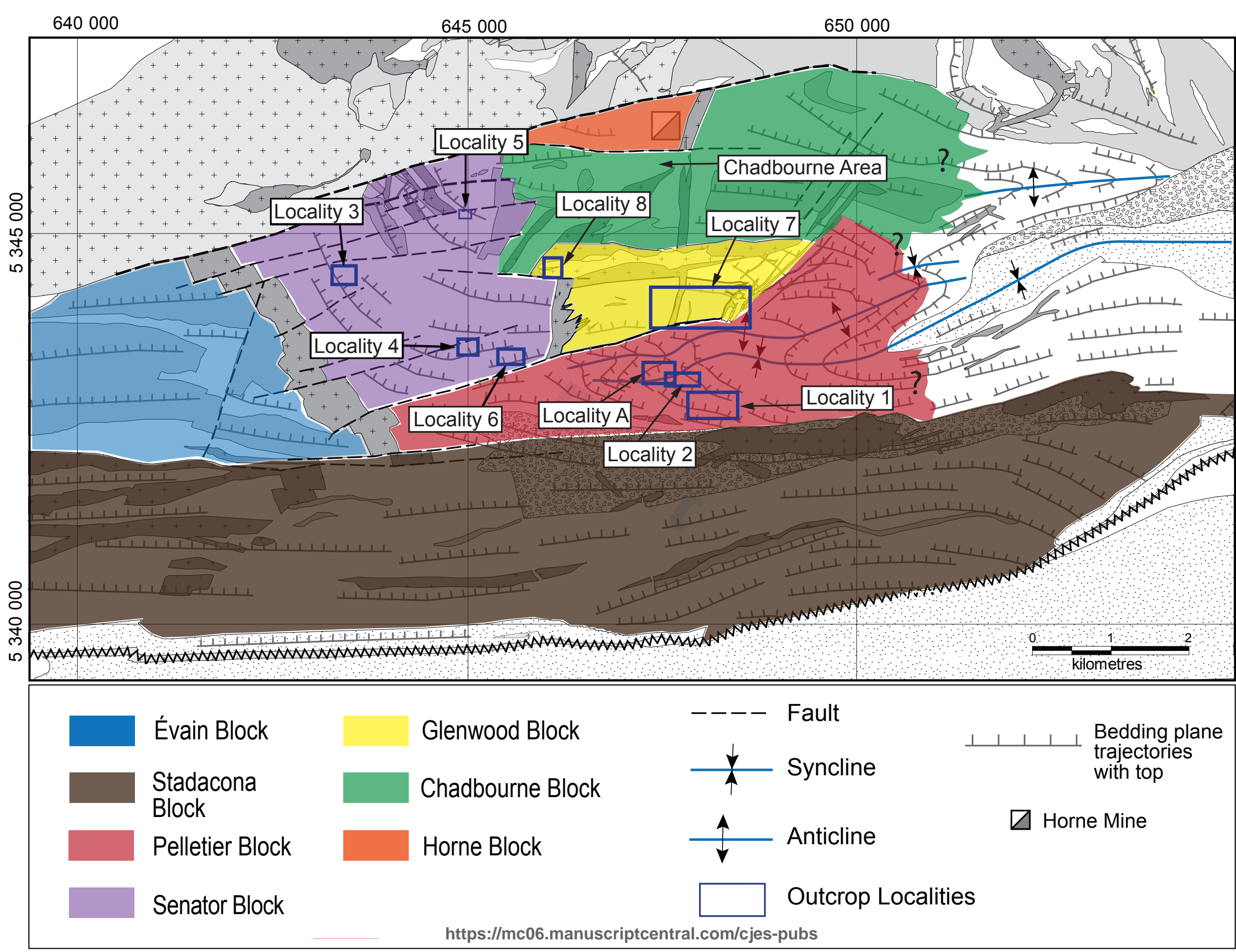




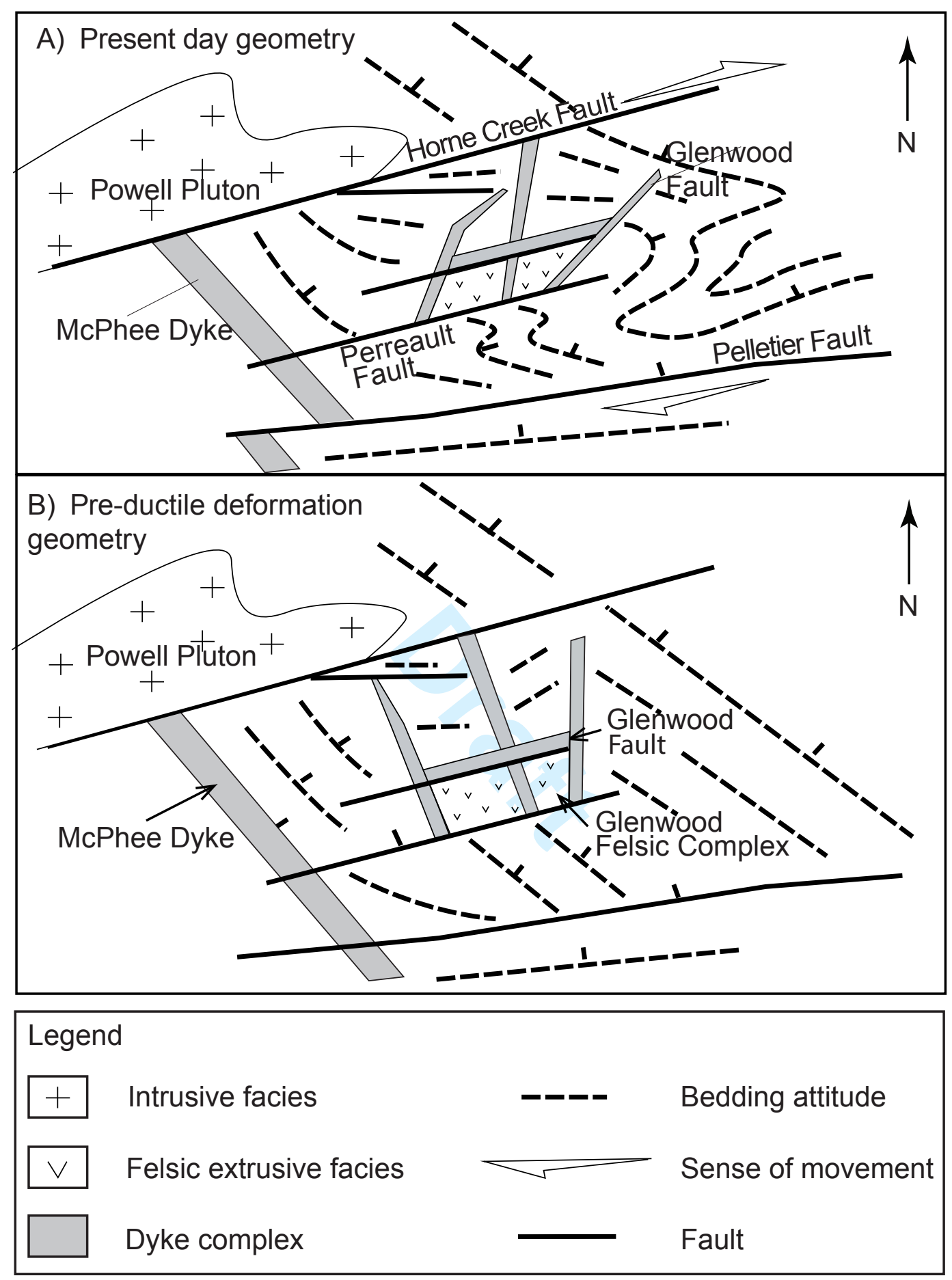




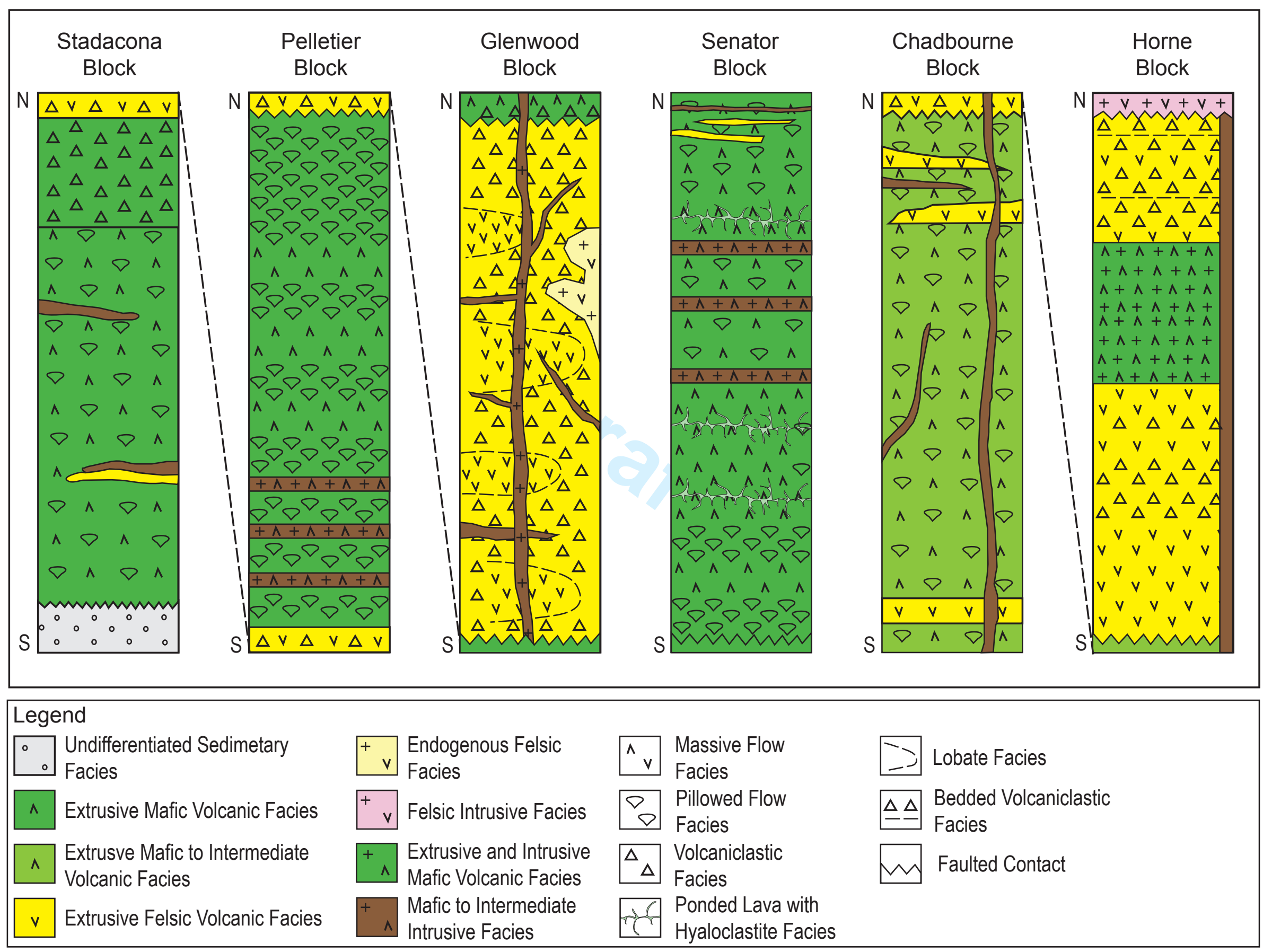




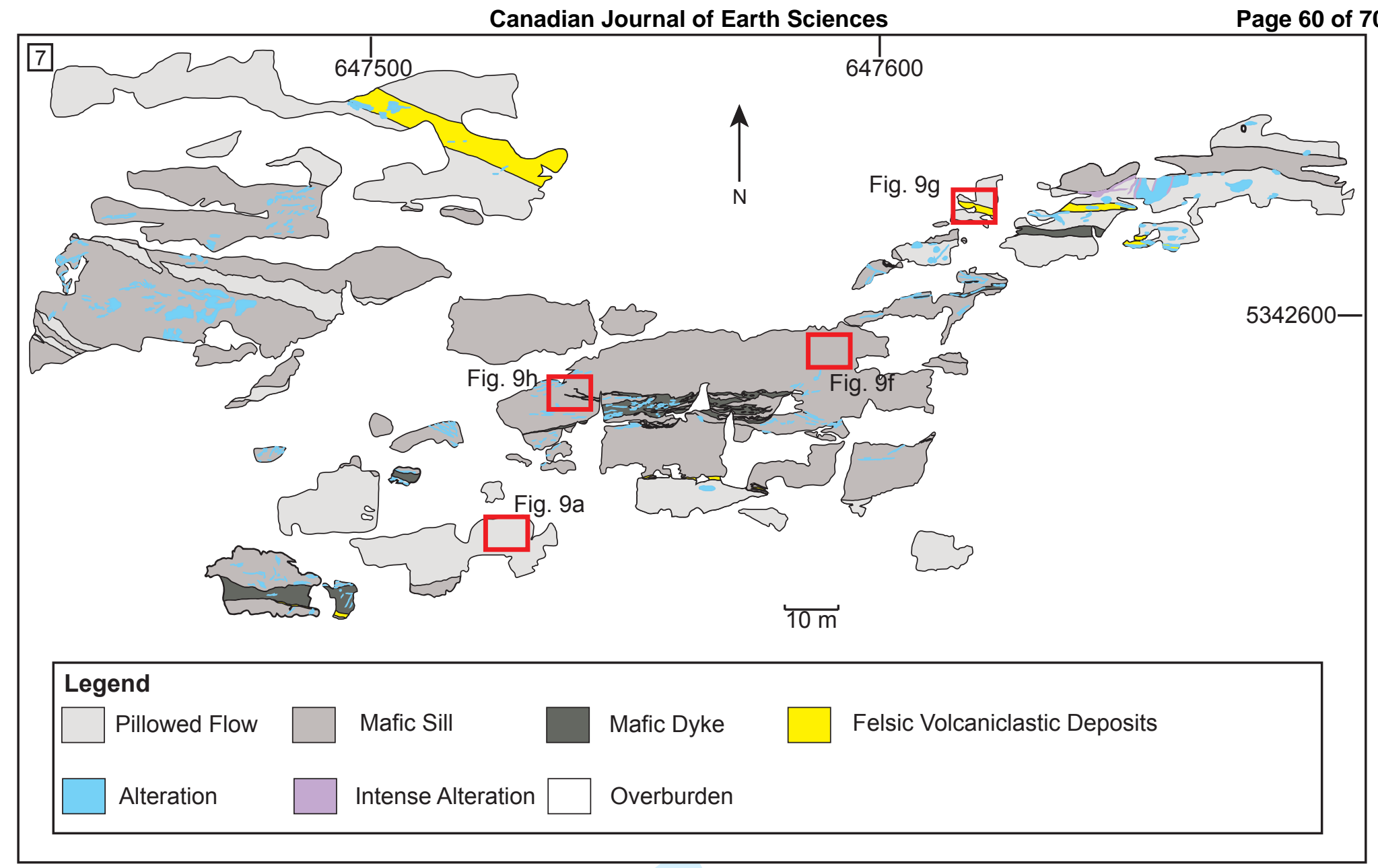




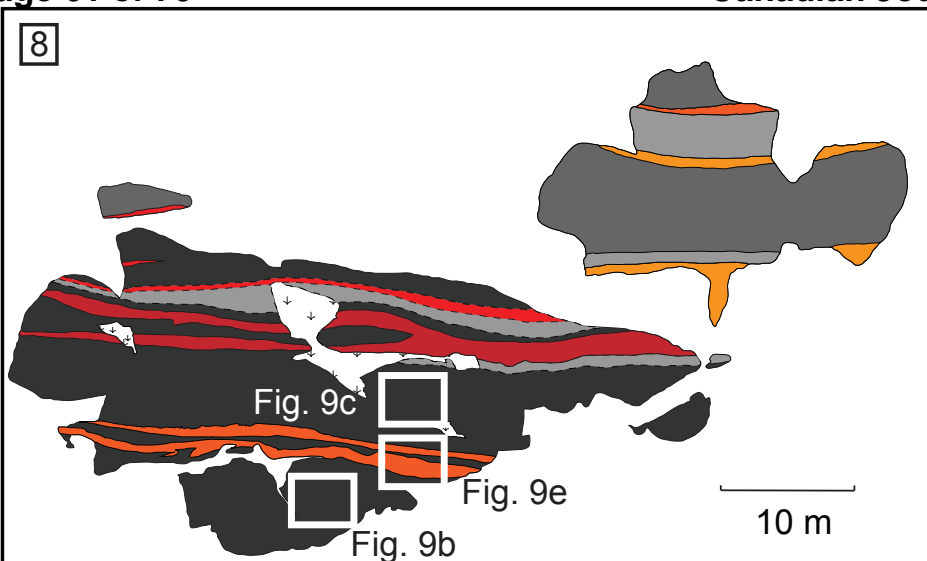
647900
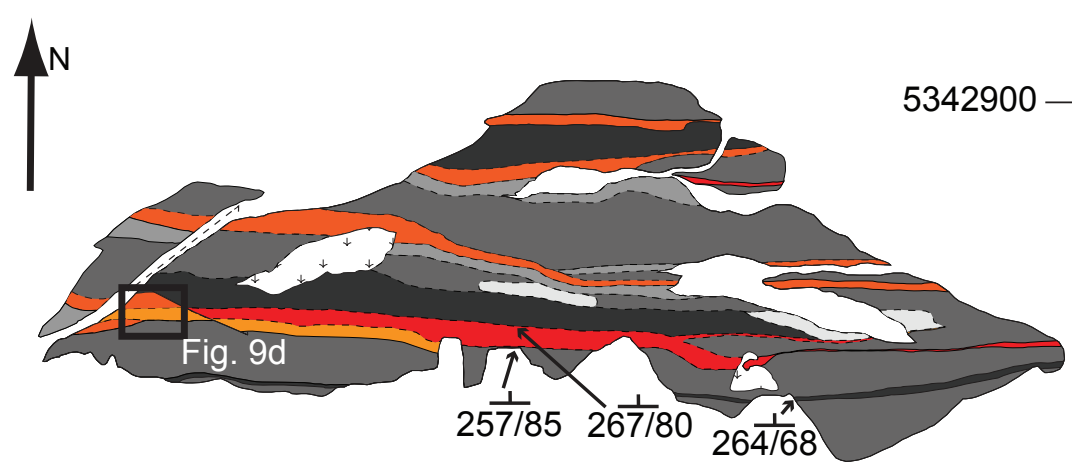

Legend

Massive Flow

Pillow Breccia in Hyaloclastite Matrix
Pillowed Flow

Pillow Rind Breccia in Hyaloclastite Matrix
Lobate Flow

Breccia in Hyaloclastite Matrix
In situ Brecciated Flow

Hyaloclastite 

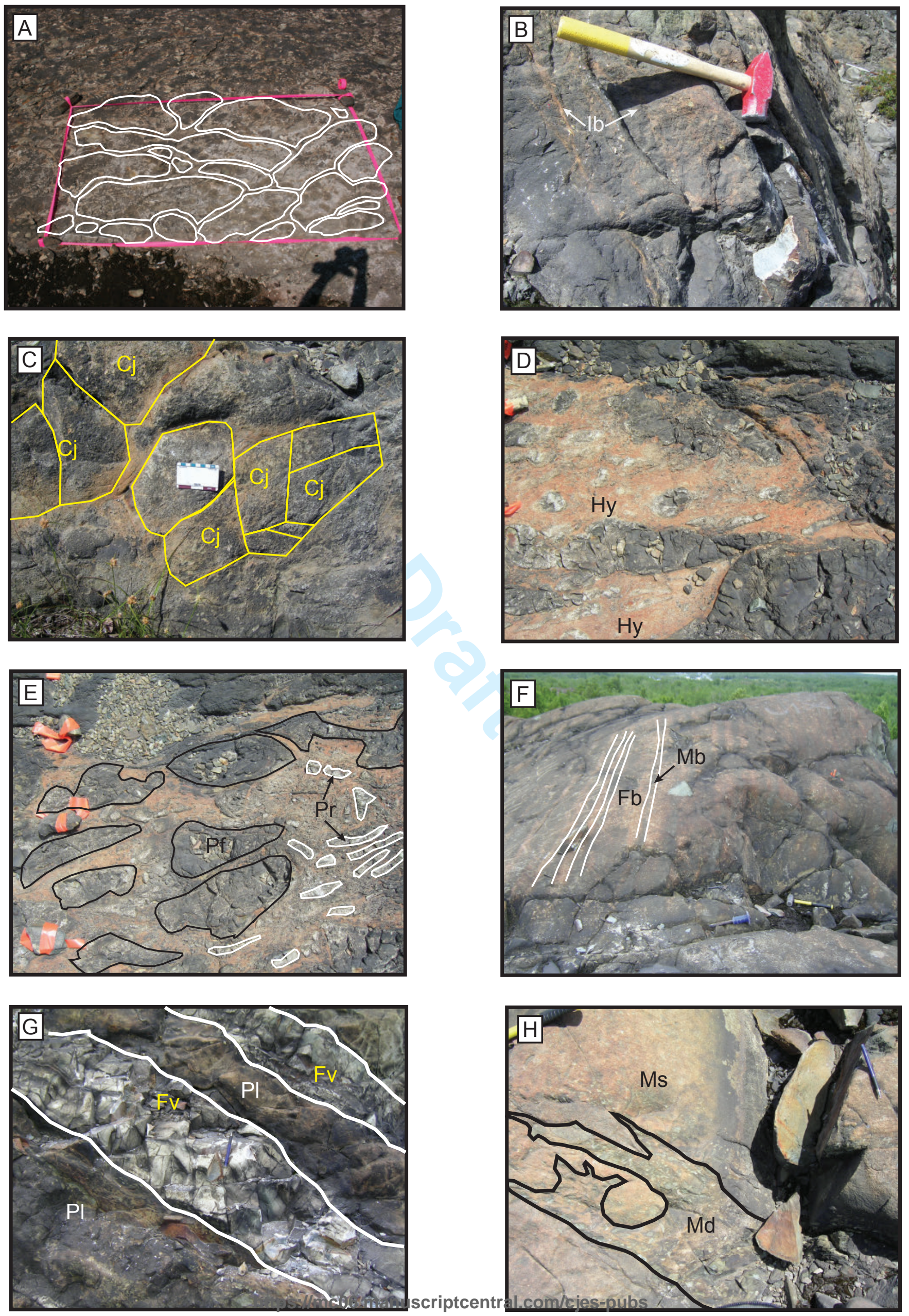


\section{Page 63 of 70}
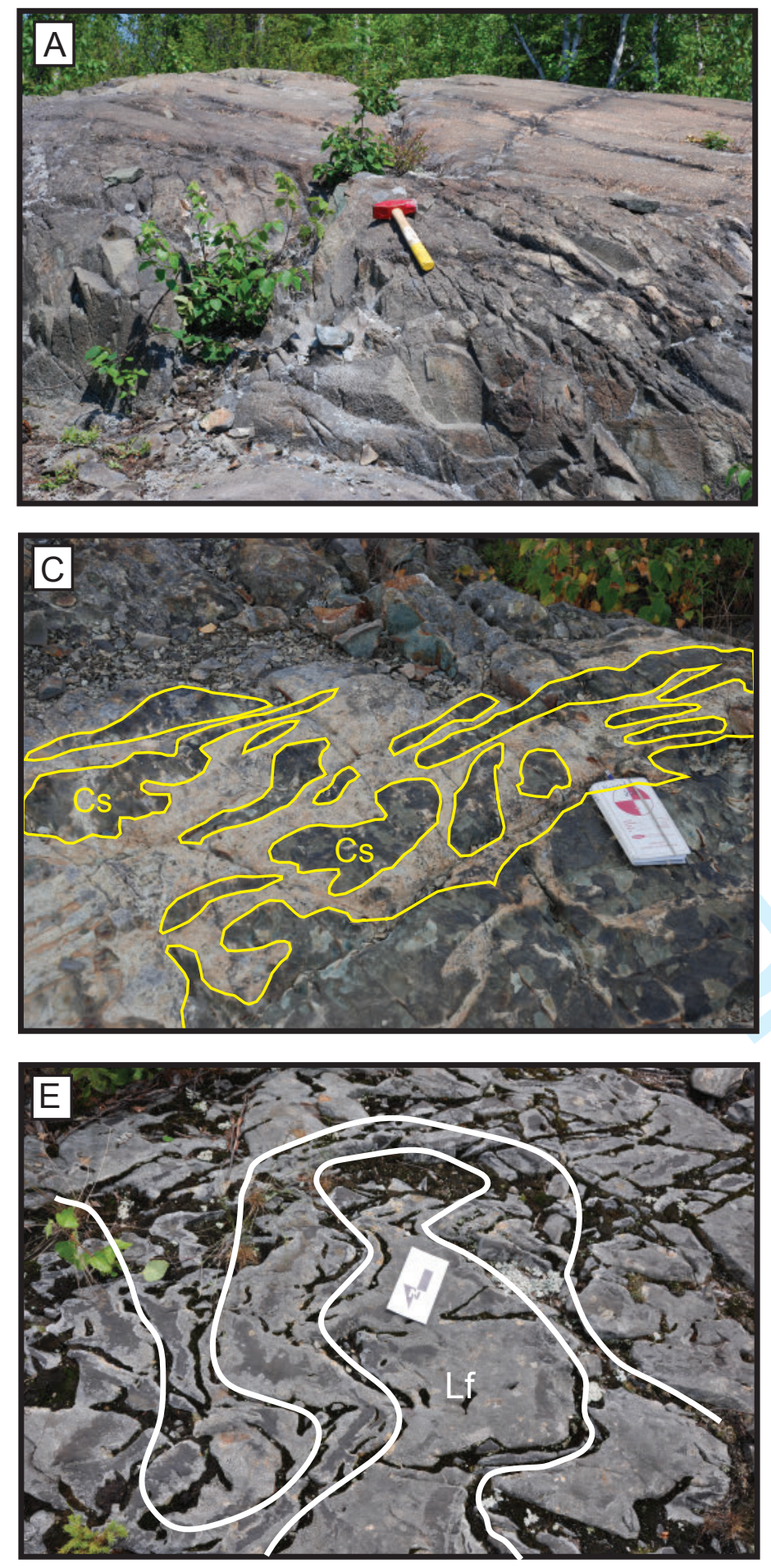
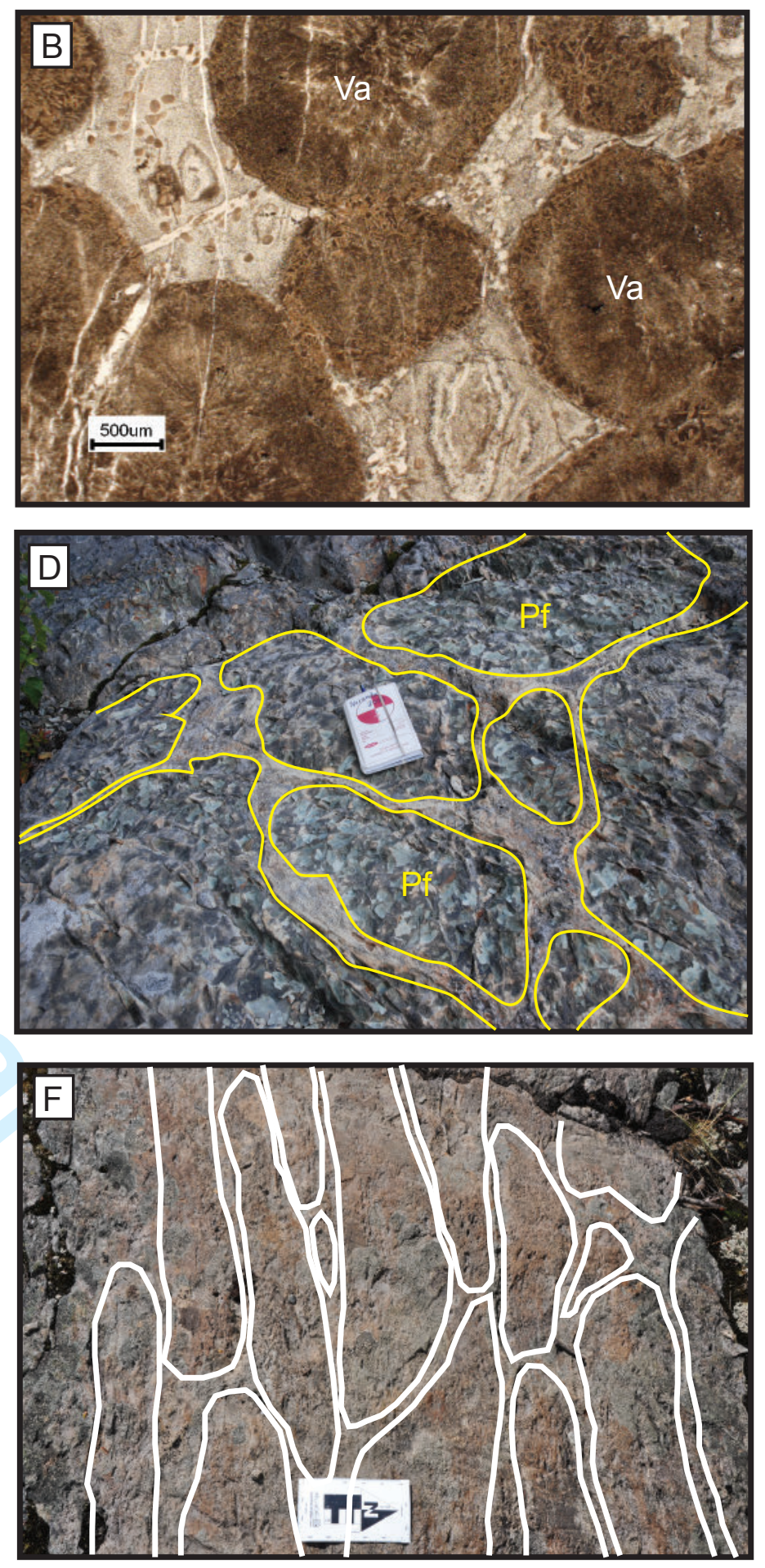


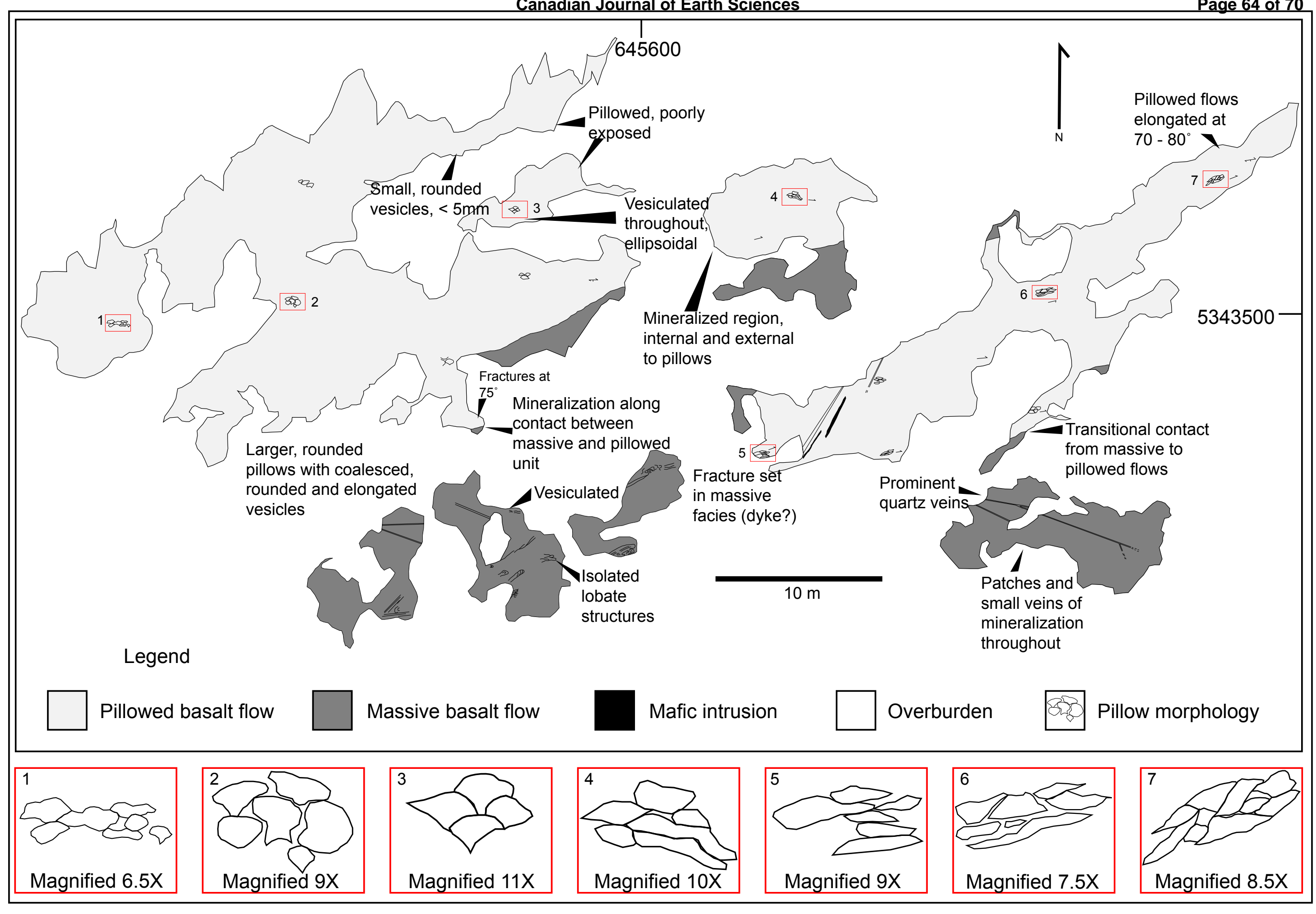



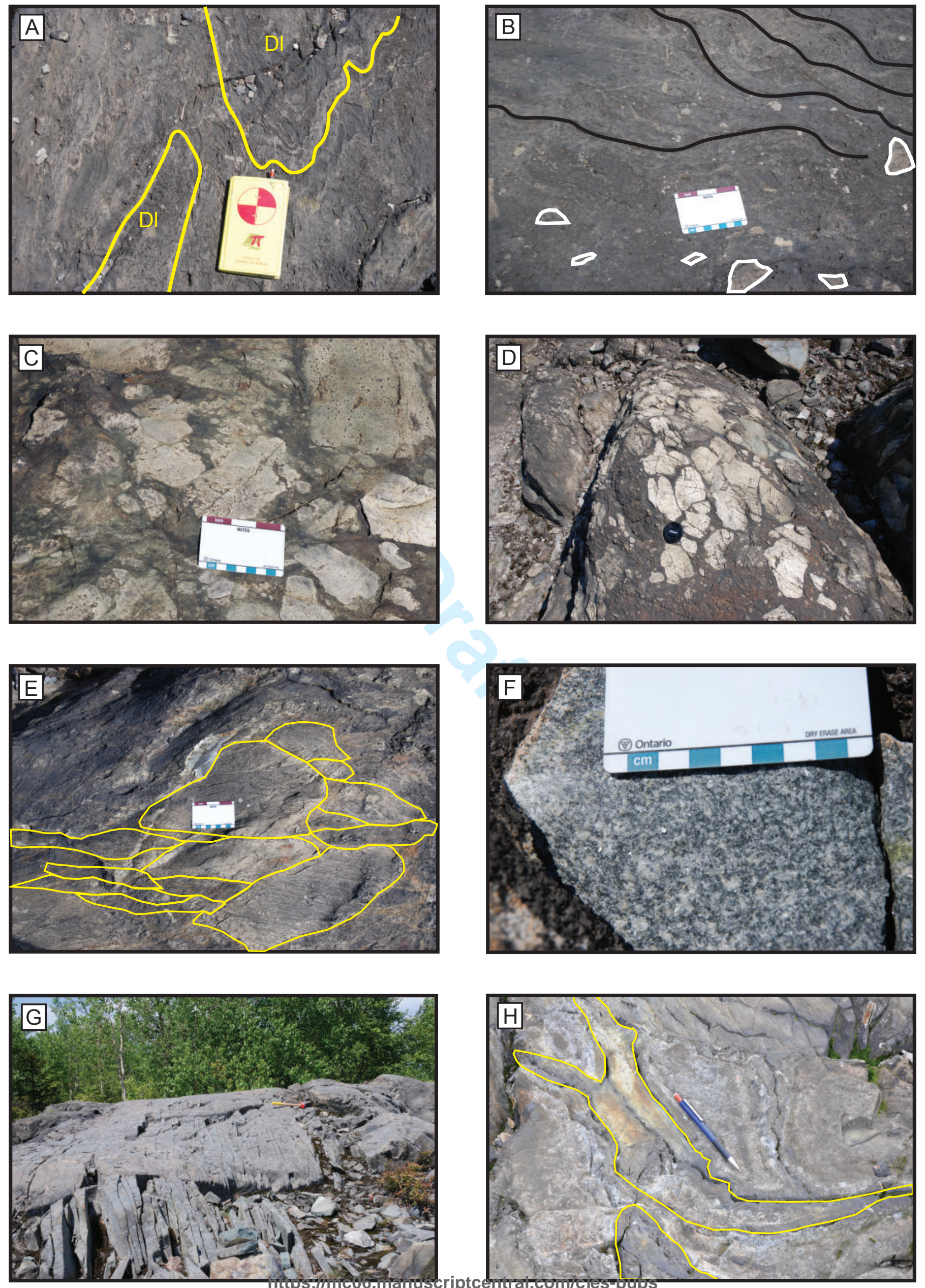


\section{Legend}

Tonalite / Quartz Diorite

Mafic Intrusion

Felsic Intrusion

Overburden

Mylonitized Zone with

Hydrothermal Alteration

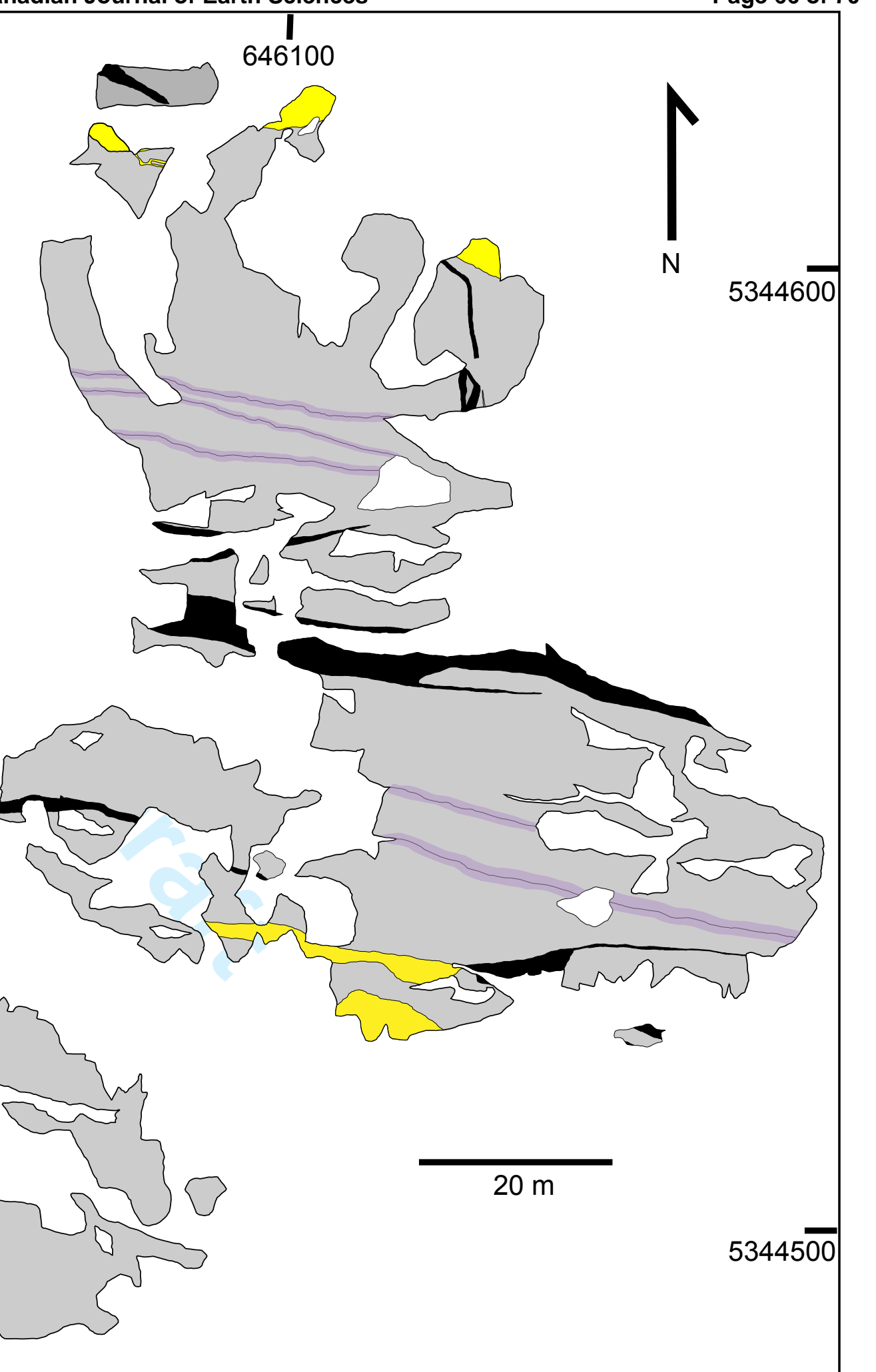




\section{Page 67 of 70}

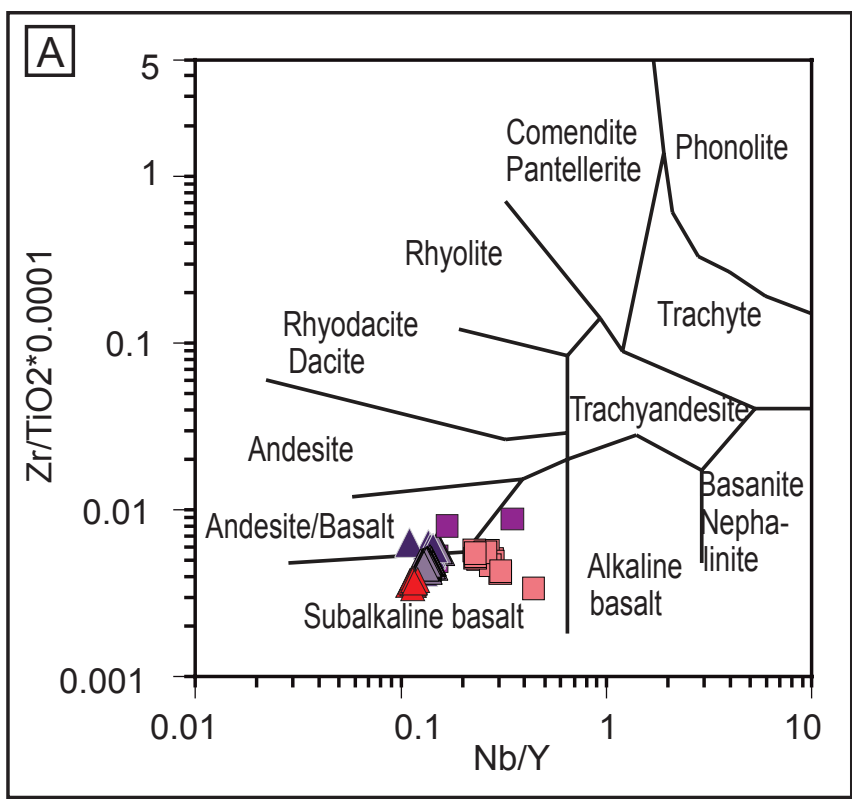

$\square \quad$ Pelletier Block Pillowed Lavas (Locality 1)

A Pelletier Block Pillowed and Massive Lavas (Locality 2)

$\triangle \quad$ Senator Block Ponded Lavas (Locality 3)

- Senator Block Ponded Lavas (Locality 4)

- Senator Block Pillowed and Massive Lavas (Locality 6)

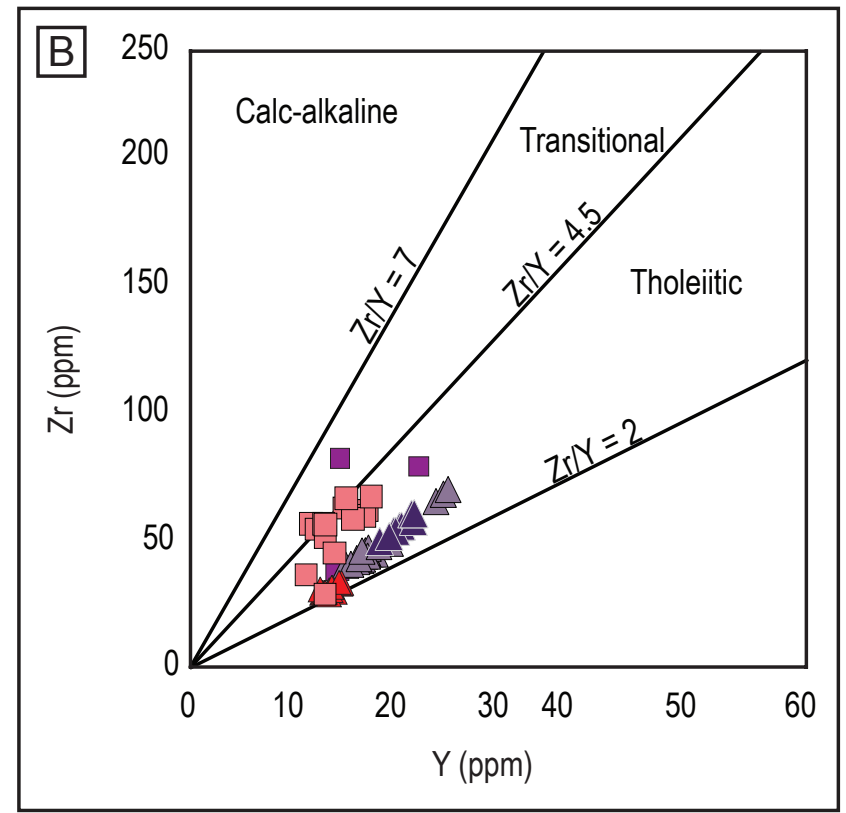

Canadian Journal of Earth Sciences

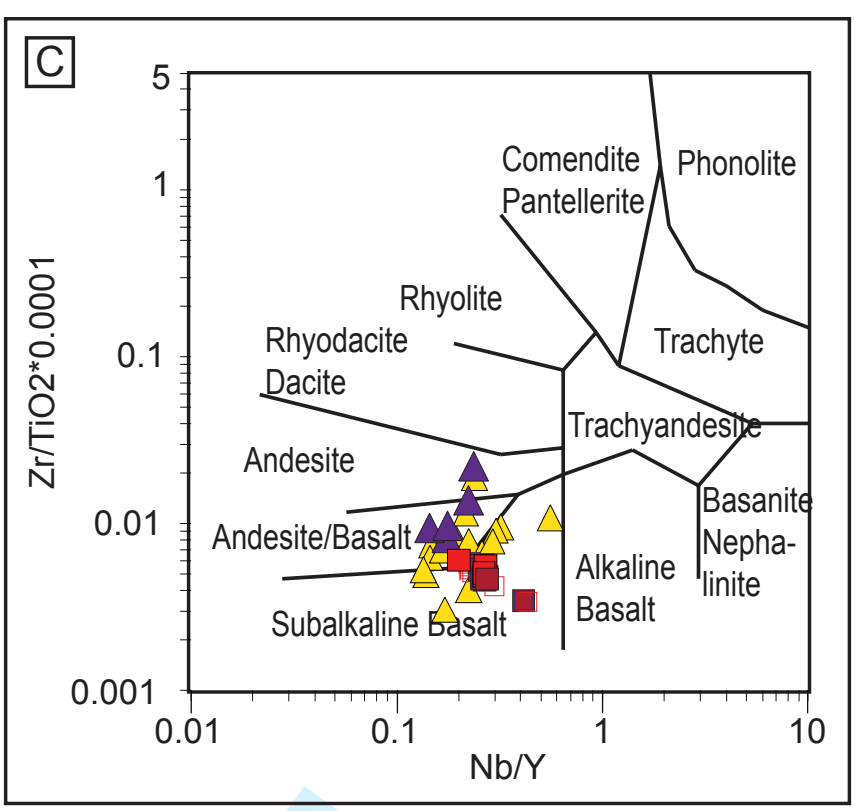

- Pelletier Block Mafic Dykes (Locality 1)

- Pelletier Block Mafic Sills (Locality 1)

- Senator Block Mafic to Intermediate Intrusions (Locality 3)

$\triangle \quad$ Glenwood Block Mafic to Intermediate Dykes (Locality 8)

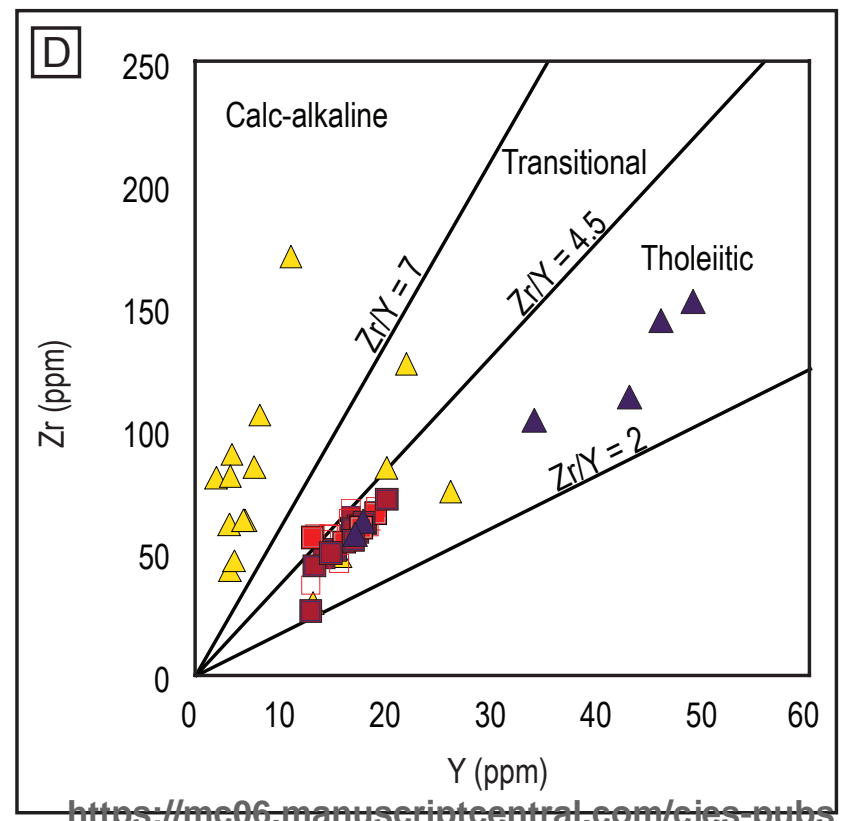

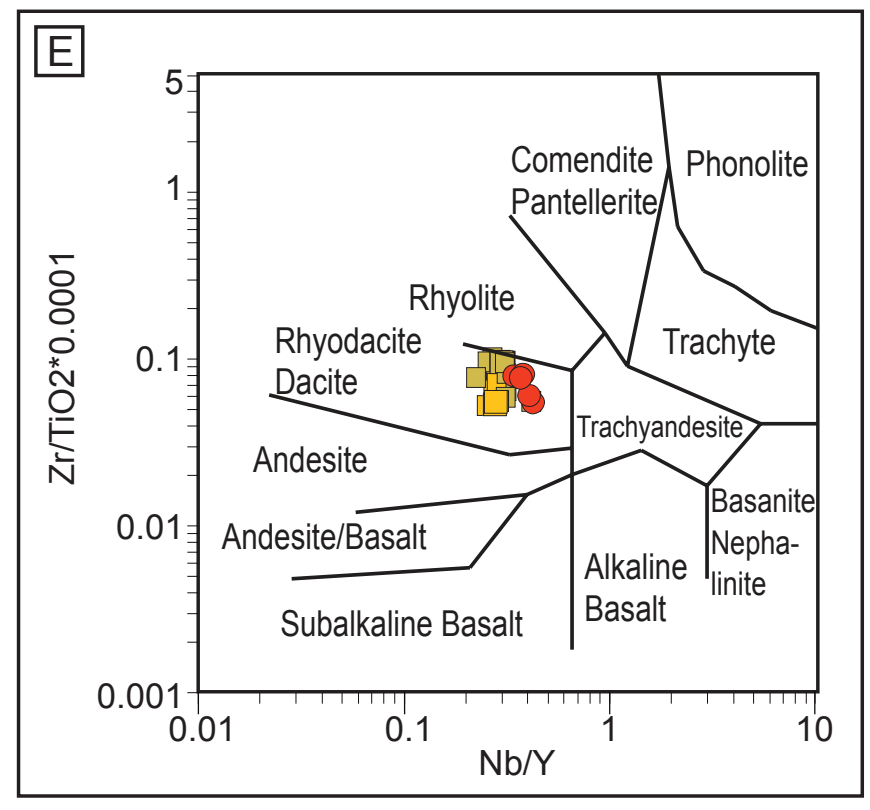

$\square \quad$ Glenwood Block Exogenous Flows (Locality 8)

$\square \quad$ Glenwood Block Endogenous Lobes (Locality 8)

$\square \quad$ Glenwood Block Intrusive Facies (Locality 7)

- Horne Block Massive Rhyolite Facies

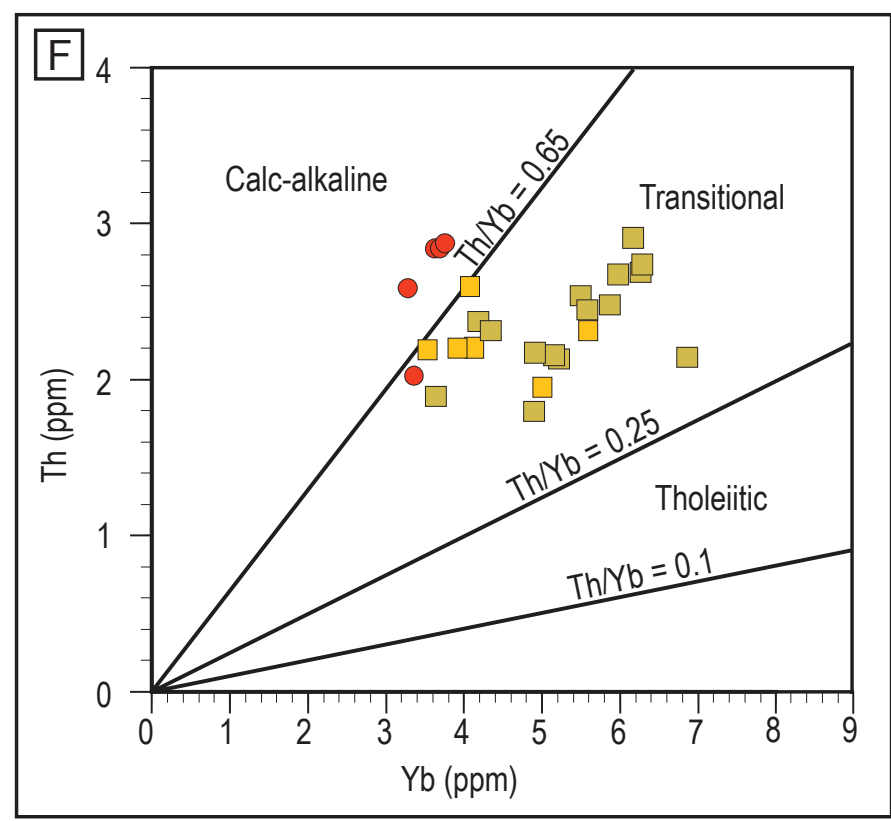




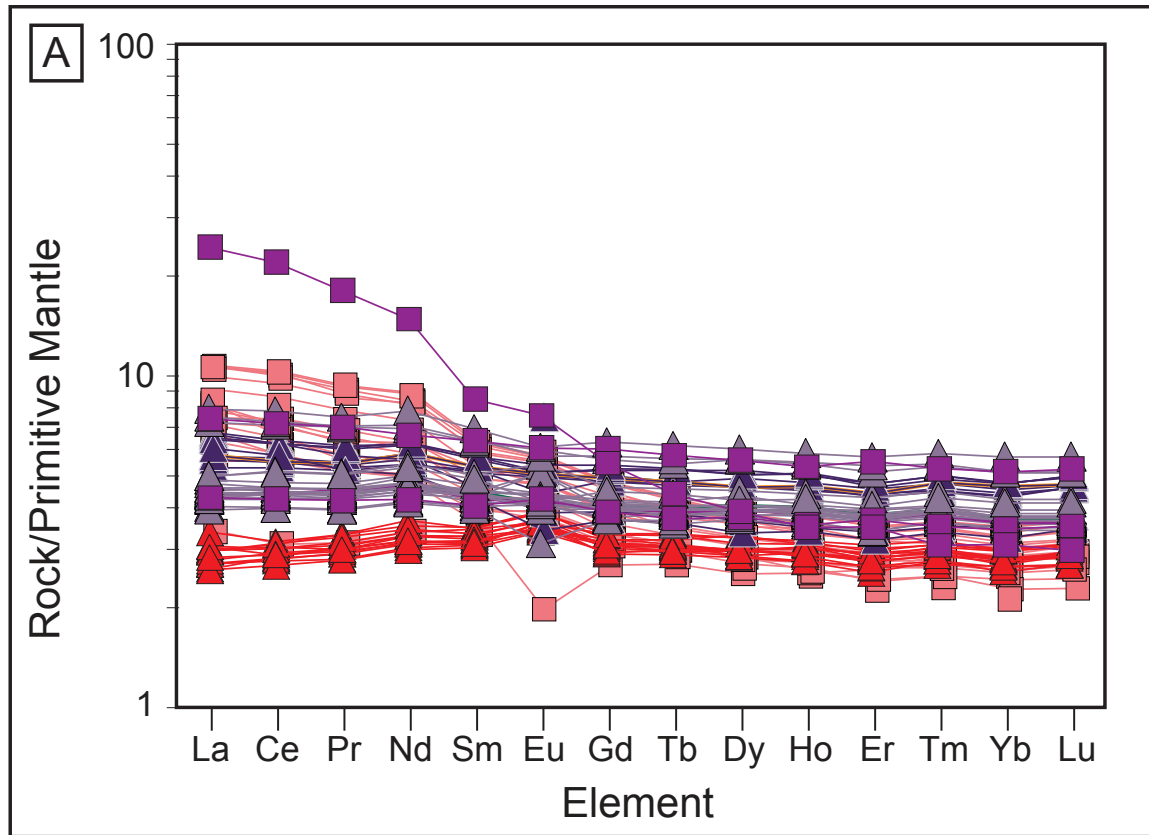

Pelletier Block Pillowed Lavas (Locality 1)

$\triangle$ Pelletier Block Pillowed and Massive Lavas (Locality 2)

$\triangle$ Senator Block Ponded Lavas (Locality 3)

A Senator Block Ponded Lavas (Locality 4)

Senator Block Pillowed and Massive Lavas (Locality 6)

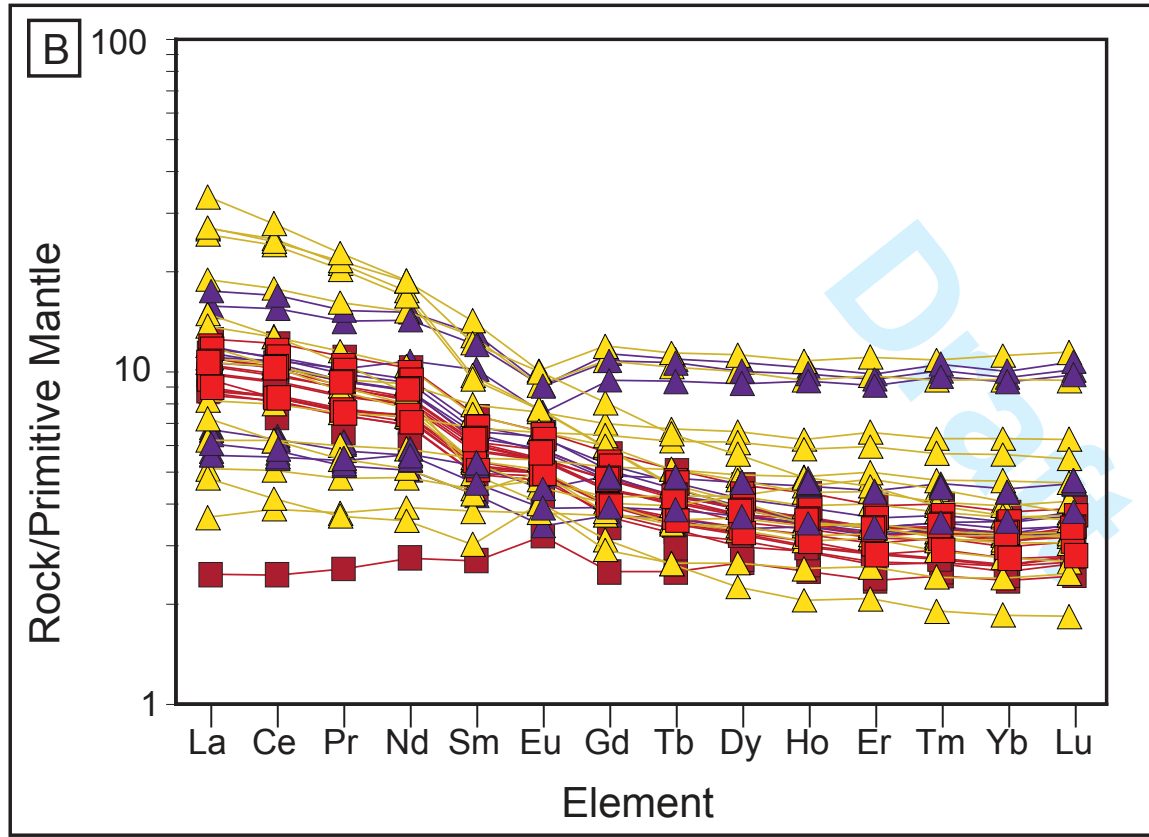

Pelletier Block Mafic Dykes (Locality 1)

Pelletier Block Mafic Sills (Locality 1)

A Senator Block Mafic to Intermediate Intrusions (Locality 3)

$\triangle$ Glenwood Block Mafic to Intermediate Dykes (Locality 8)

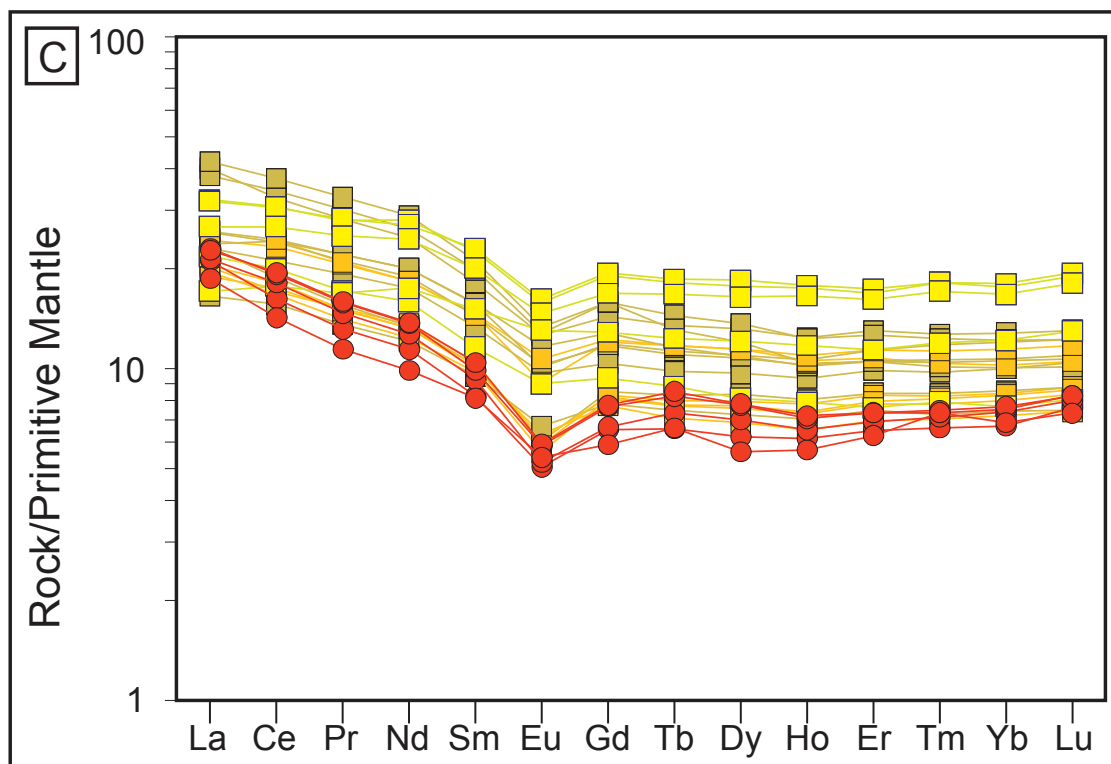

$\square$ Glenwood Block Exogenous Flows (Locality 8)

$\square$ Glenwood Block Endogenous Lobes (Locality 8)

$\square \quad$ Glenwood Block Intrusive Facies (Locality 7)

- Horne Block Massive Rhyolite Facies

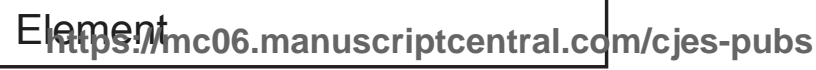



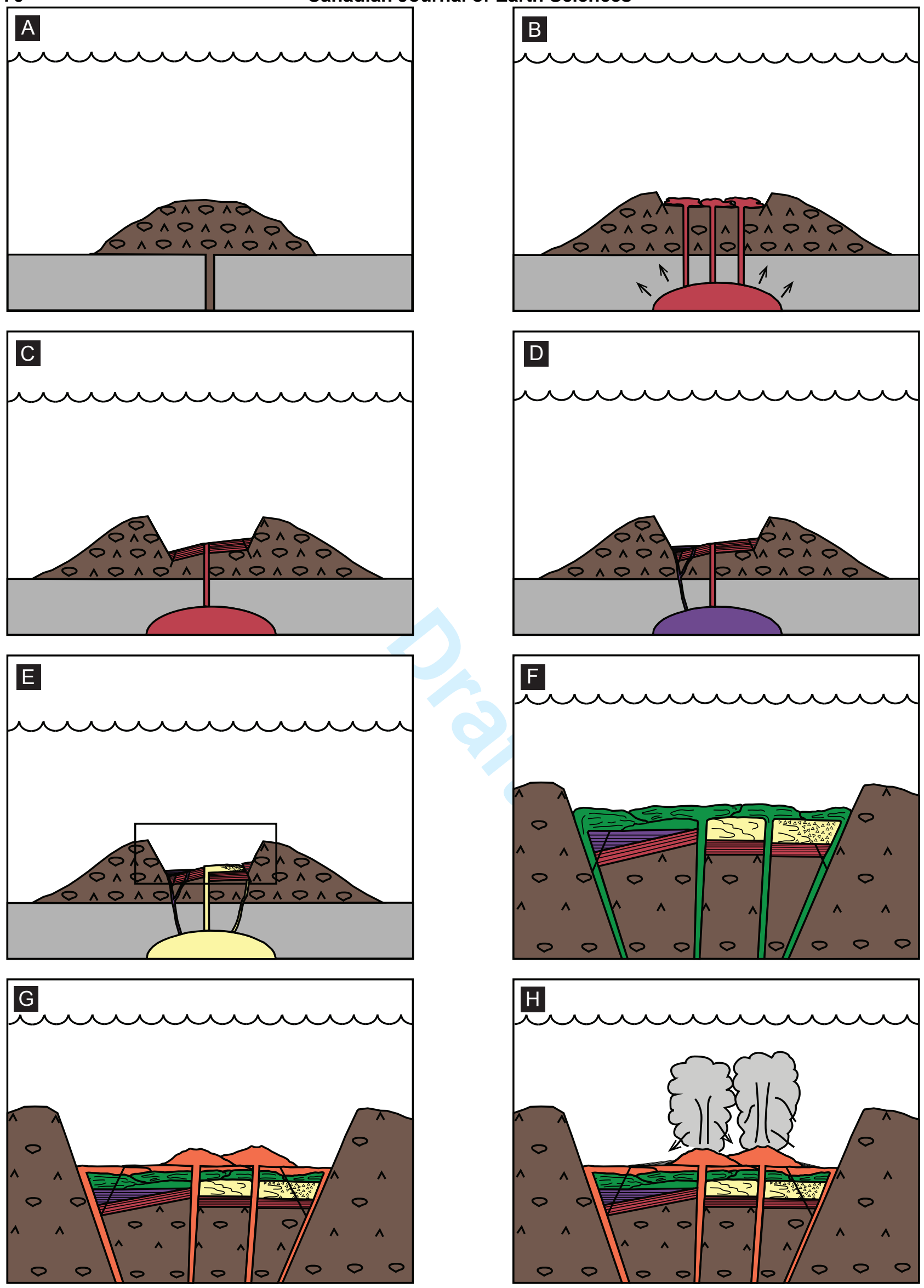

Pre-caldera facies

Glenwood block facies

Pelletier block facies

Chadbourne block facies

Senator block faciestps://mc06.manuscriptcen [ral cq4o/piestolbex facies 


\section{Blake River Group: Post $2696 \mathrm{Ma}$}

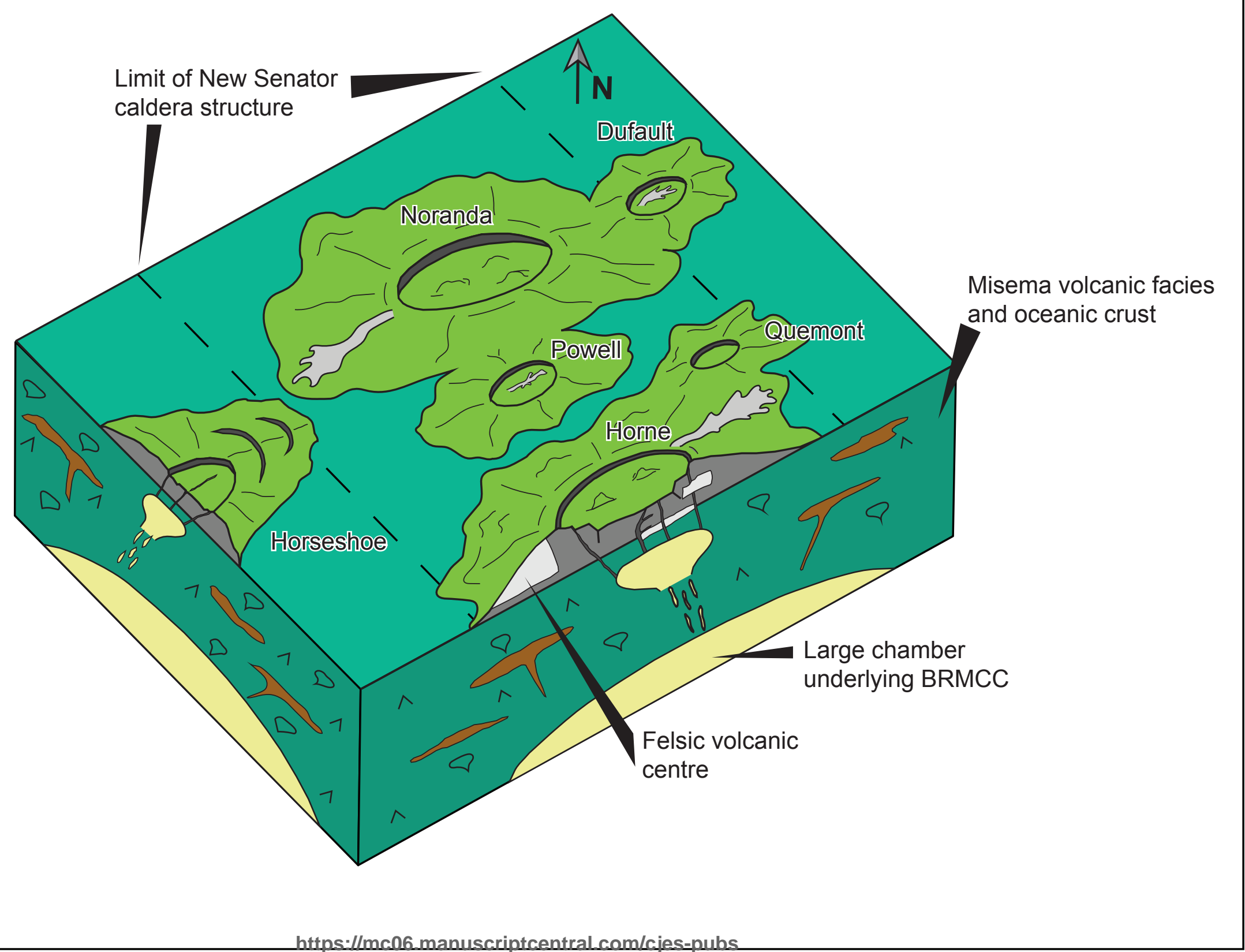

